\title{
The Ratchet Wreck: Equality's Leveling Down Problem
}

Louis Michael Seidman

Georgetown University Law Center, seidman@law.georgetown.edu

This paper can be downloaded free of charge from:

https://scholarship.law.georgetown.edu/facpub/2330

https://ssrn.com/abstract=3740127

This open-access article is brought to you by the Georgetown Law Library. Posted with permission of the author. Follow this and additional works at: https://scholarship.law.georgetown.edu/facpub

Part of the Constitutional Law Commons, and the Jurisprudence Commons 


\section{The Ratchet Wreck: Equality's Leveling Down Problem}

\section{Louis Michael Seidman*}

Constitutional equality law has a two-way ratchet problem. When someone demonstrates that a government policy treats her unequally, the injury can be remedied by improving things for the claimant, but it can also be remedied by leaving the claimant's status unchanged while making things worse for the people advantaged by the policy. ${ }^{1}$ If a court chooses the latter option, it diminishes the welfare of some people while arguably not improving welfare for anyone else. ${ }^{2}$ Why is that a good idea?

A familiar example dramatically illustrates the problem. The Supreme Court has rejected the argument that the disproportionate application of the death penalty to African Americans violates the Equal Protection Clause. ${ }^{3}$ Suppose the Court were to accept the argument. The government could remedy the problem by executing fewer African Americans, but it could also remedy the problem by executing more people of other races.

To sharpen the point with an admittedly extreme example, imagine that a condemned African American brings a suit claiming that racial disproportion in capital punishment cases

\footnotetext{
* $\quad$ Carmack Waterhouse Professor of Constitutional Law, Georgetown University Law Center. I am grateful to Einer Elhauge, Pamela Karlan, Michael Klarman, Gary Peller, David Pozen, Girardeau Spann, and Mark Tushnet for helpful comments on an earlier draft.

$1 \quad$ See, e.g., Welsh v. United States, 398 U.S. 333, 362 (1970 (Harlan, J., concurring) (where a statute is defective because of underinclusion "a court may declare it a nullity and order that the benefits not extend to the class that the legislature intended to benefit, or it may extend the coverage of the statute to include those who are aggrieved by exclusion.")

In theory, the Court could adopt an intermediate solution, extending or restricting the benefit to some but not others. But although such a compromise might solve the constitutional problem in some cases, the Court has held that such a restructuring of legislation "should not be undertaken lightly." Califano v. Westcott, 443 U.S. 76, 92 (1979).

$2 \quad$ For arguments that downward leveling does improve the status of people disadvantaged by the law or policy, see TAN xx, infra.

$3 \quad$ McCleskey v. Kemp, 481 U.S. 179 (1987).
} 
violates his equal protection right, but instead of requesting the nullification of his own death sentence, insists on the imposition of a death sentence on a similarly situated non-African American. Should a court entertain this suit?

It takes some work to explain why it should. ${ }^{4}$ Many judges would conclude that the plaintiff lacks standing to demand this remedy. ${ }^{5}$ Even if he does, many judges would conclude that executing an additional non-African American does nothing to remedy the real and immediate harm facing the condemned man, while imposing real and immediate harm on a party not before the court. ${ }^{6}$

That is not to say that it is impossible to do the work and to make the counterargument. As I explain below, ${ }^{7}$ a lot turns on whether equality protects only material welfare or whether it also protects against "expressive" or comparative harm. If condemned black defendants suffer from a dignitary injury or if freedom that is judicially cognizable or if freedom from execution is a comparative good, perhaps a court should grant the requested relief.

$4 \quad$ Cf. Christopher J. Peters, Equality Reconsidered, 110 Harv. L. Rev. 1210, 1263 (1997):

There is really only one kind of case in which prescriptive equality ever matters, in which it ever purports to tell us to do something we would not already do under some conception of nonegalitarian justice. That is the case in which a person already has been treated wrongly-- unjustly--and we must decide whether, because of that fact, to treat another similar person similarly unjustly. Someone who believes in the force of prescriptive equality will contend, at least, that a reason exists to treat the subsequent person unjustly; she might even contend that this reason is decisive in a particular case. The result, if this person gets her way, will be two instances of unjust treatment instead of only one.

5 Cf. Barr v. American Assn. of Political consultants, 140 S. Ct. 2335, 2366 (2020) (Gorsuch, J, concurring in the judgment in part and dissenting in part) (questioning whether a party would have standing to argue that someone else should be deprived of a benefit).

$6 \quad$ Cf. id. at 2365 (criticizing downward ratchet for harming "strangers to this suit.")

The most dramatic findings of the study that the Court considered in McCleskey, concerned the race of the victim, not of the alleged perpetrator. See 481 U.S., at 286. A downward ratchet might be more plausible where the equal protection violation is conceived of as the involving under protection of black victims rather than as the under protection of black defendants. For perceptive discussion, see Randall Kennedy, McCleskey v. Kemp: Race, Capital Punishment, and the Supreme Court, 101 Harv. L. Rev. 1388, 1429-40 (1988).

7 See TAN $x x-x x$, infra. 
As I will also demonstrate below, ${ }^{8}$ courts have often attempted to avoid hard questions like these by leveling up - that is by allowing advantaged persons to keep their advantage and extending that advantage to the previously disadvantaged class. ${ }^{9}$ But not always and not lately. In two recent cases, the Court required the government to level down.

In Sessions v. Morales-Santana,${ }^{10}$ the justices confronted a statute dealing with the citizenship of children born outside the United States to unmarried parents when only one parent was a United States citizen. The law provided that if the child's unmarried father was a United States citizen, the child was entitled to citizenship if the father had lived in the United States for five years prior to the child's birth. In contrast, if the unmarried mother was a United States citizen, she could transmit citizenship to her child if she has lived in the United States for only one year. $^{11}$

In an opinion written by Justice Ginsburg, the Court held that this gender-based distinction violated the equal protection component of the Fifth Amendment Due Process Clause, ${ }^{12}$ but nonetheless found that the Court was "not equipped to grant the relief MoralesSantana seeks." 13 According to the Court, if "[p]ut to the choice, Congress . . would have

\footnotetext{
$8 \quad$ See TAN $\mathrm{xx}-\mathrm{xx}$, infra.

9 See, e.g., Califano v. Westcott, 443, U.S. 76 (1979) (discrimination in provision of benefits under social security to children of unemployed men and women remedied by extending the benefit); Califano v. Goldfarb, 430 U.S. 199 (1977) (discrimination in provision of benefits under social security to widows and widowers remedied by extending the benefit); Weinberger v. Wiesenfeld, 420 U.S. 636 (1979) (discrimination in provision of social security survivorship benefits remedied by extending the benefit). See also Even H. Caminker, A Norm-Based Model for Underinclusive Statutes, 95 Yale L. J. 1185, 1186-87 (1986) (noting that courts usually chose to make "vineyards" instead of "graveyards" in remedying underinclusive statutes); Pamela Karlan, Race, Rights, and Remedies in Criminal Adjudication, 96 Mich. L. Rev. 2001, 2027 (1998) ("The few examples in ordinary equal protection of levelling down ... stand out precisely because of their rarity.")

10137 S. Ct. 1678 (2017).

$11 \quad$ Compare 8 U.S.C. $\$ 1401$ (a) (2012) (requiring five-year residency for unmarried-citizen fathers) with 8 U.S.C. $§ 1409$ (c) (requiring one-year residency for unmarried-citizen mothers).

$12 \quad 137$ S. Ct., at 1689-98.

$13 \quad$ Id.
} 
abrogated [the] exception, preferring preservation of the general rule." 14 The Court therefore solved the inequality problem by denying the more generous citizenship rule to mothers and fathers alike. The holding left non-citizen fathers no better off and made things worse for noncitizen mothers. Sadly, fewer people ended up with access to citizenship than would have had access if the suit had never been brought.

A second case produced an even more problematic outcome. In Barr v. American Assn. of Political Consultants, Inc., ${ }^{15}$ the Court confronted a challenge to a federal statute that prohibited virtually all robocalls to cell phones but made an exception for calls designed to collect debt owed to or guaranteed by the United States. ${ }^{16}$ Plaintiffs, who wished to use robocalls to engage in political speech, argued that the law violated their free speech rights.

Plaintiffs' claims were grounded in the First Amendment rather than the Equal Protection Clause, but it turns out that First Amendment doctrine has an equality component. Citing wellestablished precedent, ${ }^{17}$ the Court held that statutes discriminating based on the content of speech were subject to strict scrutiny. ${ }^{18}$ Because the distinction between government debt calls and other calls was based on content and could not survive this scrutiny, it was unconstitutional. ${ }^{19}$

Unfortunately for the plaintiffs' their victory was Pyrrhic. Instead of granting them the right to make calls, the Court again leveled down, thereby depriving government debt collectors of their statutory right. ${ }^{20}$ This outcome reproduces the oddity of the result in Morales-Santana

$14 \quad$ Id. at 1700. For a discussion of the Court's effort to resolve the ratchet problem by guessing what Congress would have wanted if it had addressed the problem, see TAN xx, Infra.

$15 \quad 140$ S. Ct. 2335 (2020).

$16 \quad$ See 44 U.S.C. $\$ 227($ b)(1)(A)(iii) (making it illegal with certain exceptions to make a call with automatic dialing system or artificial or prerecorded voice to cellular service for which party is charged "unless such call is made solely to collect a debt owed to or guaranteed by the United States.")

17 See, e.g., Reed v. Town of Gilbert, 576 U.S. 155 (2015); Police Dept. Of Chicago v. Mosley, 408 U.S. 92 (1972); Hudgens v. NLRB, 424 U.S. 507 (1971).

$18 \quad 140$ S. Ct., at 2346.

$19 \quad$ Id. at 2347.

20 Id. at 2348-54. 
by making one group of people worse off without benefiting the others, but it also creates an even deeper paradox. Bizarrely, in the name of freedom of speech, the Court's decision results in the suppression of more speech than Congress had required. ${ }^{21}$ And to make matters still worse, as discussed below, ${ }^{22}$ there are indications in the plurality opinion that ratcheting down in this fashion will become more frequent.

These anomalies are mitigated by the fact that in both cases, Court did no more than establish a default rule. ${ }^{23}$ The decisions seemingly reduce total welfare, but they leave Congress free to override the initial judgment in future cases by amending the statutes to extend, rather than withdraw the benefit. ${ }^{24}$ But in a third recent case, the Court seems to have held that it is impermissible for state courts to set a similar default rule. Instead, at least in some

21 Cf. Evan Camniker, note x, supra, at 1196) (arguing that when a statute violates the content-neutrality rule, "an inchoate First Amendment norm often prefers the remedial choice of 'more speech, not enforced silence."')

22 See TAN xx-xx, infra.

23 One should not, however, underestimate the power of default rules. Congressional inertia is a strong force that may often prevents legislative correction. See, e.g., Guido Calibresi, A Common Law for the Age of Statutes 4 (1982) (discussing legislative inertia.) Cf. Helvering v. Hallock, 309 U.S. 106, 121 (1946) ("we walk in quicksand when we try to find in the absence of corrective legislation a controlling legal principle.") See also TAN $\mathrm{xx}-\mathrm{xx}$, infra.

$24 \quad$ In state cases, the Court often remands the case to the state court to make the initial ratchet decision. See note $\mathrm{x}$, supra.

Discussion of ratchets decisions as default rules is often unnecessarily complicated by treating the problem as involving constitutional remedies. When so characterized, the problem becomes ensnared in debates about whether Congress or the courts has final remedial power. Cf. Caminker, note xx, supra, at 1190 \& n. 18 (discussing whether legislatures or courts have final authority over remedial questions). But the ratchet problem differs in an important way from most remedial disputes. Most disputes about remedy revolve around whether the remedy is entailed by the constitutional right itself, or whether it is merely a discretionary means to enforce the right. Compare, e.g., Dickerson v. United States, 530 U.S. 428, 437 (2000) (holding that Congress cannot overrule Miranda v. Arizona, 484 U.S. 436 (1966) because “Congress may not legislatively supersede our decisions interpreting and applying the Constitution") with id., at 450 (Scalia, J., dissenting) (arguing that Congress can overrule Miranda because announced "only 'prophylactic' rules that go beyond the right of compelled incrimination.") For a powerful deconstruction of this distinction, see Daryl K. Levinson, Rights Essentialism and Remedial Equilibration, 99 Colum. L. Rev. 857 (1999). Assuming arguendo that the distinction can be maintained, the ratchet issue does not implicate it. That is because equality claims by their nature can be fully remedied by an upward or downward ratchet. There is therefore usually no plausible argument that one remedy or the other is an entailment of the constitutional right. For this reason, ratchet cases are better conceptualized as instances where constitutional law provides no answer and where, therefore, the matter is left to the political branches. But see TAN $x x$, infra. 
circumstances, state courts, unlike the United States Supreme Court, are prohibited from leveling down.

The holding came in the context of a complex state program providing benefits to parents who enrolled their children in private schools. Relying on a provision in the Montana constitution that prohibited aid to any school "controlled in whole or in part by any church, sect, or denomination," 25 the Montana Court held that the aid could not flow to church-related schools. ${ }^{26}$ However, as a remedial matter, the state court chose to level down: Rather than permitting aid to only secular schools, it invalidated the entire program. ${ }^{27}$

In Espinoza v. Montana Department of Revenue, ${ }^{28}$ the United States Supreme Court reversed. Writing for the majority, Chief Justice Roberts began his analysis by pointing out that the Free Exercise Clause, like the Free Speech Clause, has an equality component. The clause “"protects religious observers against unequal treatment' and against 'laws that impose special disabilities on the basis of religious status." ${ }^{29}$ According to the Court, the Montana constitution violated this requirement by imposing a special disability on religiously affiliated schools. ${ }^{30}$

As with all equality claims, this one might be resolved by either leveling up or leveling down, and, superficially, it seems that the Court recognized this freedom. At the conclusion of his analysis Chief Justice Roberts stated that "A State need not subsidize private education. But once a State decides to do so, it cannot disqualify some private schools solely because they are

$25 \quad$ Art. X, section 6, Mont. Code Ann §15-30-3101.

26 See Espinoza v. Mont. Dept. of Revenue, 393 Mont. 446, 435 P. 3d 603 (2018).

27 See id. at 469, 435 P. 3d, at 615.

28140 S. Ct. 2246 (2020).

29 Id. at 2254-55 (quoting from Trinity Lutheran Church of Columbia v. Comer, 137 S.Ct. 2012,2021 (2017).

$30 \quad$ Id. at 2255. 
religious."31 This language would seem to leave Montana free to level down by ending its subsidy for religious and secular schools alike.

But as both Justice Ginsburg and Justice Sotomayor pointed out in their separate dissents, ${ }^{32}$ this is precisely what Montana had done. The Montana supreme court held that as a matter of state law, equality would be achieved by ending the program for all students. The Court's decision reversing that state judgment entails a holding that the state court could not level down in this fashion. ${ }^{33}$ How is that reversal consistent with the Court's own decisions in Morales-Santana and Barr leveling down and with its own statement that Montana is free to withdraw all subsidies for private education?

Here is the Court's answer:

The Montana Legislature created the scholarship program; the Legislature never chose to end it, for policy or other reasons. The program was eliminated by a court, and not based on some innocuous principle of state law. Rather, the Montana Supreme Court invalidated the program pursuant to a state law provision that expressly discriminates on the basis of religious status. ${ }^{34}$

The first half of the Court's assertion runs up against the well-established principle that except in unusual situations, ${ }^{35}$ federal law has nothing to say about whether states make law through their legislatures or their courts. ${ }^{36}$ The second half is impeached by the fact that the "state law provision" did not "discriminate[ ] on the basis of religious status." Instead, the

\footnotetext{
$31 \quad$ Id. at 2261.

32 Id. at 2279 (Ginsburg, J., dissenting); id at 2292 (Sotomayor, J., dissenting).

33 The case is therefore in tension with the Court's usual practice when it strikes down a state statute on equality grounds of remanding the case to the state courts to decide whether to level up or down. See note $x$, supra. See also Skinner v. Oklahoma, 316 U.S. 535 (1942) (remanding to state court); Orr v. Orr, 440 U.S. 268 (1979) (same); Stanton v. Stanton, 431 U.S. 7 (1975) (same).

$34 \quad 140$ S. Ct., at 2262.

35 Cf. Bush v. Gore, 531 U.S. 98, 115-131 (2000) (Rehnquist, C.J., concurring) (arguing that state courts cannot change legislative judgments about how electors are chosen in presidential elections). But cf. Arizona State Legislature v. Arizona Independent Redistricting Commn., 576 U.S. 787, 814 (2015) (reference to "legislature" in elections clause of Constitution permits redistricting by independent electoral commission).

36 See Bush v. Gore, 531, U.S. 98, 112 (Rehnquist, C.J., concurring) ("[I]n ordinary cases, the distribution of power among the branches of a State's government raise no questions of federal constitutional law.")
} 
provision, as authoritatively interpreted by the Montana Court, mandated the termination of the entire program. With no program to subsidize private education, there was no inequality and, hence, no free exercise violation.

Espinoza might be cabined or explained on the ground that the state court's result was somehow infected by its initial, mistaken assumption that the state constitutional provision was valid, ${ }^{37}$ although it is hard to see how this is so, since the provision was valid if interpreted to require equal treatment of religious and nonreligious schools. Perhaps the case is simply an anomaly. Still, when Espinoza is taken together with Morales-Santana and Barr, these recent cases are sufficient to demonstrate that our ratchet rules are in disarray.

If one looks beyond these three cases, things are actually much worse. The first Part of this Article surveys the chaotic landscape. At various times, the Court has held or implied that:

* Courts faced with an equality claim must level up; ${ }^{38}$

* Courts faced with an equality claim must level down; ${ }^{39}$

* Courts faced with an equality claim may level up or down; ${ }^{40}$

*Courts faced with an equality claim should guess whether Congress preferred leveling up or leveling down; ${ }^{41}$

* When a federal court lacks the power to order a state to level up, it should dismiss the case. ${ }^{42}$

* Because a court could theoretically level down, it should deny the equality claim entirely and therefore leave the original inequality undisturbed. ${ }^{43}$

37 See Espinoza v. Montana Dept. of Reenue, 140 S. Ct. 2246, 2262 (2020). (arguing that the Montana Court's error came at the beginning of its analysis where it found that the Montana constitutional provision did not violate the free exercise clause and that in the absence of a state law violation, the Montana Court would have had no basis for invalidating the statute).

38 See TAN $x x-x x$, infra.

39 See TAN $x x$, infra.

$40 \quad$ See TAN $\mathrm{xx}$, infra.

41 See TAN $x x$, infra.

42 See TAN $x x$, infra.

43 See TAN $x \mathrm{x}$, infra. 
Matters are still further complicated by difficult questions about standing in cases where the court ratchets down or has the potential to do so, ${ }^{44}$ by issues of severability, ${ }^{45}$ and by controversy concerning the relevance of legislative purpose in ratchet cases. ${ }^{46}$

How might we clean up the mess? A promising strategy is to map various solutions onto the functions served by equality claims in the first place. Part Two undertakes that task. Many results that otherwise seem anomalous become more plausible if one embraces a particular normative justification for the equality guarantee. For example, in the hypothetical death penalty case, an expressivist theory might justify a downward ratchet, while a welfarist theory might require an upward ratchet. The problem is that the Justices have been unable to agree on and consistently apply a single, normative justification. The ratchet wreck is therefore epiphenomenal. It is an external manifestation of the Court's confusion about the reasons for equality. Confusion about reasons unsurprisingly begets confusion in outcomes.

In Part Three, I conclude with the observation that our ratchet difficulties reflect a still deeper ambivalence about the equality requirement itself. For complicated reasons, the potential for downward ratchets is necessary to make that requirement meaningful, yet the seeming irrationality of this remedy obstructs a full-throated embrace of the equality norm.

I. Rules for Ratchets

A. Leveling by Guessing 
As noted above,${ }^{47}$ the importance of judicial leveling decisions is diminished by the fact that the Court usually, although not always ${ }^{48}$ characterizes its decision as a default rule that the political branches are free to reverse. ${ }^{49}$ Often the Court goes beyond pointing to the possibility of ex post correction and attributes its decisions to ex ante judgments by Congress. On this approach, when Congress has provided express instruction, by, for example, specifying a severability rule in case the statute is invalidated, the Court should follow the instructions. ${ }^{50}$ When Congress has not provided express instructions, the Court's role is to guess what the political branches would have wanted had they known that their initial actions violated the equality requirement. ${ }^{51}$

There is an internal logic to the guessing approach. Because equality's mandate can be satisfied by leveling either up or down, the Constitution provides no guidance as to the right outcome. ${ }^{52}$ On conventional views about the Court's role, it therefore lacks a legitimate basis for resolving the question. The only option is to turn to the political branches for a definitive decision.

Ultimately, though this flight from judicial responsibility proves an unsatisfactory solution to the ratchet problem. Congressional inertia makes default rules sticky. ${ }^{53}$ The theoretical possibility of legislative reversal should not distract us from the practical reality that the Court's ratchet decisions will often be final.

\footnotetext{
$47 \quad$ See TAN $x x$, supra.

48 See TAN $x x$, infra.

$49 \quad$ See Evan Camniker, note $x$, supra, at 1187 (making this point).

50 See, e.g., Barr v. American Association of Political Consultants, 140 S. Ct. 2335, 2349 (2020 (Kavanaugh, J., announcing the judgment of the Court) (except in extraordinary circumstances, courts should follow severability provisions.) On the relationship between severability and the ratchet problem, see note $x$, infra.

51 See, e.g., Heckler v. Matthews, 465 U.S. 728, 737 n.5 (Court should adhere to congressional preference). See also Ruth Bader Ginsburg, Some Thoughts on Judicial Authority to Repair Unconstitutional Legislation, 28 Clev. St. L. Rev. 301,317 (1979) ("the court's function, then, is to serve as a short-term surrogate for the legislature.") But see Califano v. Westcott, 443 U.S. 76, 91-92 (1979) (“We may assume arguendo that, if Congress knew in 1968 what it knows now, it might well have adopted the ... model suggested by the Commissioner. But this does not mean that the [program] should be restructured along these lines by a federal court.")

$52 \quad$ But cf. Evan Camniker, note $\mathrm{x}$, supra, at 1191-1210 (arguing that inchoate or underenforced constitutional norms can guide the decision).

53 See note $\mathrm{x}$, supra.
} 
One might explain this stickiness by insisting that the Court is very good at guessing. Perhaps there are few legislative reversals because legislatures are satisfied with what the Court has done. And if the Court were to begin making wrong guesses, then, perhaps, we could rely on post hoc legislative correction to solve the problem.

Even if one accepts this dubious explanation, however, serious problems with judicial guessing as a solution to the ratchet problem remain. First, there is a temporal difficulty. The Court is making a guess about the wishes of a past legislature, but legislative correction must come from the legislators who are now in office. There is no reason to think that the wishes of these two groups of people necessarily coincide and there is usually no evidence at all about what contemporary legislators think about the problem.

Second, there is a formal difficulty. The Constitution specifies the method by which Congress can create mandatory legal rules: passage of a bill with a with majority votes in both Houses and submission them to the President for his signature. The Constitution provides no support for the creation of mandatory legal rules by the unarticulated preferences of an unspecified number of legislators concerning a hypothetical state of affairs that has not yet come about. ${ }^{54}$

Third, the formal problem is complemented by the familiar problem of defining collective intent. Formal voting rules provide an artificial but necessary means of instantiating that intent. When no formal vote is taken - indeed, when most of the potential voters have not even thought about the problem - determining a hypothetical collective intent is necessarily an exercise in projection rather than discovery. ${ }^{55}$

54 See, e.g., John C, Grabow, Congressional Silence and the Search for Legislative Intent: Adventure into "Speculative Unrealities, 64 B.U. L. Rev. 737, 746 (arguing that Congress cannot legislate by silence). See generally, Laurence H. Tribe, Toward a Syntax of the Unsaid: Construing the Sounds of Congressional and Constitutional Silence, 57 Ind. L. J. 515 (1982).

$55 \quad$ See, e.g., Antonin Scalia \& Bryan A. Garner, Reading the Law: The Interpretation of Legal Texts 392 (2012) (arguing that collective intent is "pure fiction" because legislators have their own subjective views about what they 
Finally, even if these arguments are unpersuasive, there are strong indications that the Court itself has disowned the guessing approach. In Barr, Justice Kavanaugh, writing for a plurality of the Court, ${ }^{56}$ acknowledged that in the past, the Court had searched for "indicia of congressional intent, ${ }^{, 57}$ but expressly rejected this approach:

[E]xperience has shown that this formulation often leads to an analytical dead end. That is because courts are not well-equipped to imaginatively reconstruct a prior Congress' hypothetical intent. ${ }^{58}$

Instead of attributing its decision to Congress, Justice Kavanaugh formulated the Court's own rule, which he took responsibility for creating. ${ }^{59}$

Moreover, even apart from the Court's recent, explicit statement in Barr, we have evidence from the Court's prior opinions. In many cases, it has purported to guess at Congress's hypothetical intent, but in many other cases, it has insisted on its own solution. The next Parts provide examples of both approaches.

\author{
B. Leveling Up
}

are voting on, or no views at all). But cf. Caleb Nelson, What Is Textualism?, 51 Va. L. Rev . 347, 362 (2005) (arguing that it is sensible to ask whether interpretive tool tends to minimize or aggregate gap between what legislators thought they were adopting and how statute is interpreted); Kurt Greenawalt, How Law Can Be Determinate, 38 U.C.L.A. L. Rev. 1, 20 (1990) (outlining circumstances under which collective intent can be determinate).

56 Justice Kavanaugh wrote only for himself and Justices Roberts and Alito. Barr v. American Assn. of Political Consultants, 140 S. Ct. 2335, 2341 (2020). In separate opinions, Justice Sotomayor and Justice Breyer, joined by Justices Ginsburg and Kagan, agreed that the Court should ratchet down but expressed no views about why this was the right result. Id. at 2357 (Sotomayor, J., concurring); id. at 2363 (Breyer, J., concurring).

$57 \quad$ Id. at 2350.

$58 \quad$ Id.

59 Id. at 2353. See also Califano v. Westcott, 443 U.S. 76, 91-92 (1979) (declining to restructure the statute in the way that, Court assumed arguendo, Congress would have preferred).

As a formal matter, the Barr Court addressed its rule to the issue of severability rather than ratcheting. In equal treatment cases, however, the two issues overlap. If the provision unconstitutionally extending the benefit is severed, then the Court levels down. If the offending provision is found nonseverable, then the Court levels up. For example, in Barr, the Court found that the provision granting government debt collectors the right to make robocalls was severable. The result was that no one was permitted to make such calls - a downward ratchet. Had the entire provision outlawing robocalls been invalidated, then everyone would have been permitted to make them - an upward ratchet. See also note $\mathrm{x}$, infra. 
Assuming that the Court is not merely reflecting inchoate legislative will, how should it resolve ratchet controversies? The simplest way is to level up. By granting a benefit to the disadvantaged class, the court remedies the equality problem without reducing the welfare of the advantaged class. Presumably for this reason, ratcheting up has been the standard remedy for inequality. ${ }^{60}$ In many cases, courts do not even entertain the possibility of doing anything else. ${ }^{61}$ Few people thought that ending the right of straight people to marry was a possible remedy for the failure to recognize gay marriage ${ }^{62}$ or that the remedy for California's failure to subsidize appeals for indigent criminal defendants was denying everyone a right to appeal. ${ }^{63}$ Even in cases where ratcheting down is a more plausible alternative, courts have frequently not bothered to discuss it. ${ }^{64}$ And when they have discussed the problem, they have often concluded that ratcheting up is the more sensible solution. ${ }^{65}$

As discussed above, courts have usually also recognized that they are making default judgments. They have not denied the power of legislature or, in state cases, state courts, to

\footnotetext{
60 See note $\mathrm{x}$, supra.

61 For example, in Roman Catholic Diocese of Brooklyn v. Cuomo, 592 U.S. _ (2020), the Court granted emergency injunctive relief against a state regulation issued in conjunction with the Covid crisis that limited attendance at religious institutions while not imposing similar limits on businesses the Governor had deemed "essential." Neither the Justices in the majority nor those in the dissent considered the possibility of ratcheting down by imposing similar restrictions on the "essential" businesses.

$62 \quad C f$. Obergefell v. Hodges, 576 U.S. 644 (leveling up to guarantee the right to same-sex marriage.) But cf. Martha C. Nussbaum, A Right to Marry?, 98 Cal. L. Rev. 667, 694 (2010) (asking whether "government [should] continue to marry people at all?")

Leveling down is not an option where an independent constitutional provision guarantees the right of the advantaged class to the benefit. See Deborah L. Brake, When Equality Leaves Everyone Worse Off: The Problem of Leveling Down in Equality Law, 46 Wm. \& Mary L. Rev. 513, 553-54 (2004); Evan H. Caminker, note x., supra, at 1187, n. 8. Caminker expands on this point to argue persuasively that independent, but inchoate or underenforced constitutional norms should sometimes control the ratchet decision. See id., at 1191-1209.

$63 \quad$ Cf. Douglas v. California, 372 U.S. 353 (1963) (resolving equality problem with regard to indigent defendants by leveling up).

64 See, e.g., Jiminez v. Weinberger, 417 U.S. 628, 637-38 (1974) (leveling up without explanation); Frontier v. Richardson, 411 U.S. 677, 691 n. 25 (1973) (same).

65 See note $x$, supra.
} 
remedy the equality problem by depriving the favored class of its benefits. ${ }^{66}$ Indeed, in some state cases, the Supreme Court has remanded to the state court to make the initial ratchet decision. $^{67}$

In a few notable cases, however, the Court has seemingly insisted on ratcheting up. I have already discussed one example: In Espinoza, the Court refused to permit the state supreme court to ratchet down by ending the aid program for all students. Instead, it insisted that the state ratchet up by extending the program to students wishing to use the aid to attend sectarian schools. $^{68}$

For reasons that remain obscure, the Court has also held that leveling up is constitutionally required in cases where a defendant is criminally convicted under a discriminatory statute. In Grayned v. City of Rockford, ${ }^{69}$ the Court reversed the defendant's criminal conviction under an antipicketing statute because the statute had an exception for labor picketing. ${ }^{70}$ After defendant's conviction, the legislature repealed the labor exception, thereby leveling down, but the Court held that this subsequent action was irrelevant because "we must consider the facial constitutionality of the ordinance in effect when appellant was arrested and convicted."71 The Court left unclear why the government could solve an inequality problem with downward leveling in a civil, but not a criminal context.

66 See,e.g., Stanton v. Stanton, 421 U.S. 7, 18 (1975)(noting that "the appellant, although prevailing here on the federal constitutional issue, may or may not ultimately win her lawsuit.")

67 See, e.g., Wengler v. Druggist Mut. Ins. Co., 446 U.S. 142m 152-53 (1980); Stanton v. Stanton, 421 U.S. 7, 18 (1975); Skinner v. Oklahoma, ex rel. Williamson, 316 U.S. 535, 543 (1942).

68 See TAN xx-xx, supra.

$69 \quad 408$ U.S. 104 (1972).

$70 \quad$ Id. at 107.

71 Id. at 107 n. 2. See also Sessions v. Morales-Santana, S. Ct. 1678, 1699 n. 23 (2017); Welsh v. United States, 398 U.S. 333, 361-64 (1970) (Harlan, J., concurring in the result). 
These cases might be dismissed as aberrational. As I've discussed above, Espinoza arose in an unusual posture because the state court's ratchet decision was premised on a state constitutional provision that, the United States Supreme Court thought, was itself unconstitutional. $^{72}$ A special rule for criminal cases might be justified based on the ban on ex post facto criminal punishment. ${ }^{73}$

The result in Griffin v. County School Bd. of Prince Edward County, ${ }^{74}$ is more difficult to cabin. At the height of "massive resistance" to Brown v. Board of Education, ${ }^{75}$ school officials in Prince Edward County, Virginia, responded to a desegregation order by refusing to levy taxes to support public education and closing all public schools. Private schools were established to educate white children and, the state legislature provided tuition assistance and tax credits on a nonracial basis to children attending private schools. Parents of African Americans refused the aid, and the result was that many African American children did not attend school for four years while the litigation progressed. ${ }^{76}$

On these facts, the Supreme Court held that the school closing was unconstitutional. ${ }^{77}$ Although the Court did not use ratchet language, the effect of its decision was to prevent the state from ratcheting down. The state had "solved" the equality problem by depriving all children of a public education, but the Court held that this solution was unconstitutional and that the inequality had to be remedied by providing all children a public, nonsegregated education.

See TAN xx, supra.

See United States Constitution, Art. I, §10, cl.1.

377 U.S. 218 (1964).

347 U.S. 483 (1954).

377 U.S., at 222-24.

Id. at 233-34. 
Two obvious explanations for the Court's decisions do not quite do the trick. First, the Court gestured toward a claim that the ratchet-down solution violated the equal protection clause because both black and white students in Prince Edward County were discriminated against when compared to students in the rest of Virginia, who could attend public schools. ${ }^{78}$ But having made this suggestion, the Court quickly disowned it:

[T]here is no rule that counties, as counties, must be treated alike; the Equal Protection Clause relates to equal protection of the laws "between persons as such rather than between areas." .. . A State, of course, has a wide discretion in deciding whether laws shall operate statewide or shall operate only in certain counties, the legislature "having in mind the needs and desires of each." A State may wish to suggest . . that there are reasons why one county ought not to be treated like another. ${ }^{79}$

Second, the Court emphasized the state financial support for the segregated, private schools that were serving white students. ${ }^{80}$ True, black students were at least theoretically also eligible for tuition grants, but Brown had already held that segregated public education was "inherently unequal." ${ }^{\prime 1}$ It was not a big stretch to find that state-funded segregated private education was also unconstitutional.

But if this was the problem, then the apparent solution would be invalidation of the tuition grant program, and, indeed, the Court did just that. ${ }^{82}$ In an unusual (for desegregation cases in this era) separate opinion, Justices Clark and Harlan indicated that they would have stopped there. ${ }^{83}$ The majority disagreed. Even without public funding for private schools, the Court held, Prince Edward county was obligated to level up by reopening its schools rather than to level down by leaving them closed.

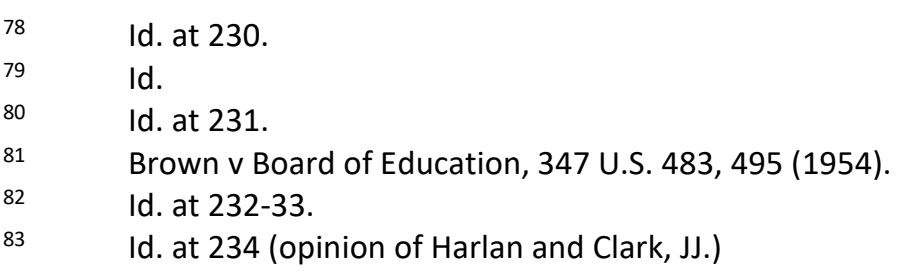


Having flirted with these unsatisfactory explanations, the Court finally came to the point.

In a striking passage, the Court asserted:

the record in the present case could not be clearer that Prince Edward's public schools were closed and private schools operated in their place with state and county assistance, for one reason, and one reason only: to ensure, through measures taken by the county and the State, that white and colored children in Prince Edward County would not, under any circumstances, go to the same school. Whatever nonracial grounds might support a State's allowing a county to abandon public schools, the object must be a constitutional one, and grounds of race and opposition to desegregation do not qualify as constitutional. ${ }^{84}$

At first, it might seem that this reasoning has the same flaw that makes the result in Espinoza troubling. Given the setting in which the case was decided, there can be no doubt that the Court was correct about the motivation of state officials. The question, though, is why that motivation made their actions unconstitutional. If it is really true that equality problems can be resolved by leveling down as well as by leveling up, then, it would seem, there is no constitutional difficulty with treating all children equally badly by closing public schools. Just as the Montana legislature could constitutionally end all tuition grants rather than providing them to children attending sectarian schools, so too, Prince Edward County could constitutionally end all public education rather than providing it in racially desegregated form. And if it is constitutional to adopt this "remedy," then it is hard to see why the "object" of doing so is unconstitutional.

There are nonetheless ways to understand the Court's reasoning that might explain the outcome. First, the Court might be understandably concerned that the threat to ratchet down would deter efforts to vindicate equality rights. If potential litigants can expect no gain from the litigation, why go to the trouble? ${ }^{85}$ The point is especially powerful in Prince Edward, where

\footnotetext{
$84 \quad$ Id. at 231.

85 Cf. Burr v. American Assn. of Political Consultants, 140 S. Ct. 2335, 2366 (2020) (Gorsuch, J., concurring in the judgment in part and dissenting in part) ("What was the point of fighting this long battle, through many years and all the way to the Supreme Court, if the prize is winning no relief at all?")
} 
there was actually a double downward ratchet. In most such cases, the status of the disadvantaged party remains unchanged, while the status of others deteriorates. But in Prince Edward, the African American plaintiffs also suffered injury when they were denied not only integrated public education, but also segregated public education.

The point is reenforced, or perhaps merely recharacterized, if phrased in terms of Article III standing requirements. In general, plaintiffs have access to federal courts only if they can demonstrate that they have suffered an "injury in fact," that the injury is caused by the government action they object to, and that the injury that will be remedied by the relief that the court will provide. ${ }^{86}$ When a court levels up, all three requirements are satisfied. The unequal denial of the benefit constitutes the injury in fact, the denial of the benefit is caused by the putatively unconstitutional denial of equality, and the provision of the benefit remedies the violation. But if the court is free to level down, then there is a problem with two of the three requirements. ${ }^{87}$ Leveling down means that the unequal treatment has not caused the plaintiff's injury and that the court's judgment will not remedy it. The prospect of leveling down, in turn, means that it is "merely "speculative"" that the decree will remedy plaintiff's injury. ${ }^{88}$ We would then be confronted with the disturbing possibility that plaintiffs might never have standing to

86 See, e.g., Lujan v. Defenders of Wildlife, 504 U.S. 555, 560 (1992) (setting out these three factors as the "irreducible constitutional minimum" to establish Article III standing.)

87 For a discussion of how the Court has solved the problem, see TAN xx, infra.

88 See Lujan v. Defenders of Wildlife, 504 U.S. 555, 560 (1992) ("it must be 'likely' as opposed to merely 'speculative' that the injury will be 'redressed by a favorable decision.'”) (quoting Simon v. Eastern Ky. Welfare Rights Org., 421 U.S. 26, 41-42 (1976).) 
bring equality claims. The implausibility of that result, ${ }^{89}$ in turn, argues for a mandatory upward ratchet. ${ }^{90}$

Second, the Court may well have believed that the decision to ratchet down, like the decision to segregate public schools in the first place, was motivated by racial animus and by the desire to preserve a more general, unconstitutional racial hierarchy. This concern was especially salient in the era of "massive resistance" directed against the Court's effort to end officially sanctioned Jim Crow. As the Court put the point, "[w]hatever nonracial grounds might support a State's allowing a county to abandon public schools, the object must be a constitutional one, and grounds of race and opposition to desegregation do not qualify as constitutional." 91 Perhaps the outcome in Espinoza could be similarly explained. Several of the justices wrote about how antiCatholic animus motivated the constitutional prohibition on aid to sectarian schools. ${ }^{92}$ On this view, Montana Supreme Court's decision to level down gave effect to Montana law infected by religious bias.

These arguments, in turn, might form the basis for a general rule favoring mandatory upward ratchets. It will often - perhaps always - be the case that the prospect of a downward ratchet will discourage suits to enforce equality rights, and there will often be problems of explaining why a plaintiff has standing when the result of the suit is a downward ratchet.

$89 \quad$ Cf. Orr v. Orr, 440 U.S. 268, 272 (1979) (argument that leads to the conclusion that there is no standing in every equal protection attack on a statute challenged as underinclusive "proves too much.") But cf. Schlesinger v. Reservist Committee to Stop the War, 418 U.S. 208, 227 (1974) ("The assumption that if respondents have no standing to sue, no one would have standing, is not a reason to find standing.") For a discussion of the relationship between standing and ratchet issues, see TAN xx, infra.

$90 \quad$ See Tracy Thomas, Leveling Down Gender Equality, 42 Harv. J. Law \& Gender 177, 206-207 (2019) (arguing that leveling down is inconsistent with standing requirements.)

91377 U.S., at 231.

92 See 140 S. Ct., at 2259 (Roberts, C.J.) (linking Montana "no aid" provision to Blaine Amendment, which was "born in bigotry" toward Catholics); id at 2266 (Thomas, J.) (arguing that separationist views are sometimes motivated by hostility to disfavored religions); id at 2267-74 (Alito, J.) (linking Montana "no aid" provision to Blaine Amendment and anti-Catholic bias.) 
Animus toward the disadvantaged class may not always be as obvious as it was in the context of massive resistance to Brown, but it is nonetheless a real possibility whenever the legislature chooses to deprive everyone of benefits rather than to extend them to the disadvantaged class. Indeed, as discussed below, a prominent defense of the equality right is based on just this possibility. ${ }^{93}$ Defenders of equality argue that the requirement that benefits be equally extended "smokes out" government policies based on nothing more than animus. They insist that if there is no good explanation for the failure of government to extend a benefit to equally situated people, the inference is strong that the failure is based on a bad reason. If that is true, then arguably the inference becomes even stronger when the government is willing to go so far as to withdraw previously granted benefits to the advantaged class so as to avoid benefiting the disadvantaged class. ${ }^{94}$

For these reasons, a court that was so inclined could have built on Prince Edward to create a more general presumptive or absolute upward ratchet requirement. In fact, though, in the wake of Prince Edward, the Court moved in the opposite direction.

In Palmer v. Thompson, ${ }^{95}$ the Court faced a set of facts closely analogous to those in Prince Edward. Like Prince Edward County, Jackson, Mississippi operated a segregated government facility - in this case, municipal swimming pools. As in Prince Edward County, a court order declared the segregation unconstitutional, and like Prince Edward County, Jackson responded by closing the facility.

On this occasion, though, the Court in an opinion by Justice Black, who had also authored Prince Edward, held that leveling down was constitutionally permissible. In the

See TAN xx-xx, infra.

See id.

403 U.S. 217 (1971). 
Court's view, the city was under no constitutional obligation to operate swimming pools in the first place, ${ }^{96}$ and closing the pools for black and white patrons alike established equality. ${ }^{97}$ The Court distinguished Griffin on the ground that there the state had supported private segregated schools, whereas in Palmer, there was no allegation that the state was supporting private, segregated swimming pools. ${ }^{98}$ It provided no explanation for why if this was the problem in Prince Edward, prohibiting state subsidies to private, segregated schools was not a sufficient solution.

What about the problem of animus toward the disadvantaged class? In Prince Edward, Justice Black had written that "[w] hatever nonracial grounds might support a State's allowing a county to abandon public schools, the object must be a constitutional one, and grounds of race and opposition to desegregation do not qualify as constitutional." 99 It was similarly obvious that Jackson had closed its swimming pools to avoid integration, and the Court nowhere denied this fact. Justice Black conceded that his own language in Griffin might make legislative purpose relevant to constitutionality, ${ }^{100}$ but he now claimed that "the focus ... was on the actual effects of the enactments," rather than on motive or purpose. 101 "No case in this Court," Black insisted, "has held that a legislative act may violate equal protection solely because of the motivations of the men who voted for it."102

$96 \quad$ Id. at 220. Although neither the Griffin Court nor the Palmer Court mentioned the possibility, the two cases might be distinguished on the ground that there is a fundamental right to public education but not to public swimming pools. Compare San Antonio Independent School Dist. v. Rodriguez, 411 U.S. 1 (1973) (holding that there is no fundamental right to education) with Plyler v. Doe, 457 U.S. 202, 224 (1982) (holding that discrimination against undocumented persons with respect to public education "can hardly be considered rational unless it furthers some substantial goal of the State.")

$97 \quad$ Id. ("this is not a case where whites are permitted to use public facilities while blacks are denied access.")

$98 \quad$ Id. at 221-22.

$99 \quad 377$ U.S., at 231.

$100 \quad 403$ U.S., at 225.

101 Id.

102 Id. 
More recently, Palmer itself has fallen into disfavor. In Washington v. Davis, ${ }^{103}$ the Court announced the "basic equal protection principle" that "the invidious quality of a law claimed to be racially discriminatory must ultimately be traced to a racially discriminatory purpose"104 and dismissed Palmer's contrary language as "dicta."105 Moreover, as noted above, several justices in Espinoza pointed to the discriminatory purpose of Montana's "no aid" provision in the course of insisting on an upward ratchet. ${ }^{106}$

In light of these developments, one cannot dismiss mandatory upward leveling as a solution to the ratchet problem. Still, the modern Court has also downplayed the risk of deterring equality suits, arguing that plaintiffs will be sufficiently motivated by the possibility of an upward ratchet or by the naked desire to be treated equally. ${ }^{107}$ Similarly, it has said that removing an obstacle to an upward ratchet is sufficient relief to establish standing ${ }^{108}$ or, more recently, that the remedied injury is not the material deprivation but the mere refusal to provide equal treatment. ${ }^{109}$

The upshot is that although the Court's dominant approach permits upward or downward leveling, mandatory upward ratchets are not off the table. Even more surprisingly, though, there

\footnotetext{
103426 U.S. $229(1976)$.

$104 \quad$ Id. at 240.

105 Id. at 242. In the wake of Washington, the Court has invalidated facially neutral laws solely because of their discriminatory purpose. See Hunter v. Underwood, 471 U.S. 222 (1985) (invalidating provision of Alabama Constitution disfranchising all persons convicted of misdemeans of moral turpitude because motivated by desire to disfranchise African Americans). Cf. Ramos v. Louisiana, 140 S. Ct. 1390, 1394 (2020) (noting that origin of permission for nonunanimous jury verdicts in criminal cases was "to establish the supremacy of the white race.")

106 See TAN xx, supra.

107 See, e.g., Barr v. American Assn. of Political Consultants, 140 S. Ct. 2335, 2355 (arguing that providing equal treatment remedied constitutional injury); id. at n. 13 (2020) (arguing that "many individuals and organizations often have incentive to challenge unequal treatment.")

108 See, e.g., Orr v. Orr, 440 U.S. 268, 273 (1979) (holding that plaintiff has standing even though winning lawsuit "holds only the promise of escape from the burden.")

109 See Northeastern Florida Chapter of Associated General Contractors of America v. City of Jacksonville, 508 U.S. 656, 666 (1993); Regents of University of California v. Bakke, 438 U.S. 265, 281 n. 14 (1978) (Powell, J., announcing the judgment of the Court). See also TAN xx-xx, infra.
} 
are also more than a few cases that not only reject mandatory upward ratchets, but also insist on mandatory downward ratchets. The next Part turns to those cases.

\section{Leveling Down}

As already noted, the Supreme Court endorsed downward ratchets in Santana-Morales and Barr, ${ }^{110}$ but these are not the first cases where it has suggested that equality problems must be resolved by making things worse for the advantaged class. ${ }^{111}$ The import of these earlier cases has been obscured by the Court's choice to talk about the problem in terms of standing and severability rather than ratchets, but careful analysis makes clear that the three problems intersect.

In some of these cases, the Court recognized the theoretical possibility of a downward ratchet and held that that possibility did not destroy standing. For example, in Orr v. Orr, ${ }^{112}$ the Court invalidated a state statute that provided that husbands but not wives could be awarded alimony upon divorce. Faced with a challenge to the plaintiff's standing on the ground that the state might respond by leveling down, the Court stated that "this argument quite clearly proves too much." "113 That was so because "[i]n every equal protection attack upon a statute challenged as underinclusive, the State may satisfy the Constitution's commands either by extending benefits to the previously disfavored class or denying benefits to both parties.... Unless we are to hold that all underinclusive statutes can never be challenged because any plaintiff's success can

\footnotetext{
110 See TAN xx, supra.

111 Cf. National Life Ins. Co. v. United States 277 U.S. 508. 534-35 (1928) (Brandeis, J., dissenting) (arguing that unconstitutionality of discriminatory taxation should be remedied by denying deduction); Ruth Bader Ginsburg, Some Thoughts on Judicial Authority to Repair Unconstitutional Legislation, 28 Clev. St. L. Rev. 301, 31819, 323-24 (1979) (suggesting that leveling down may be appropriate where remedy impacts a large class and imposes financial costs on private parties.)

112440 U.S. 268 (1979).

$113 \quad$ Id. at 272.
} 
theoretically be thwarted, Mr. Orr must be held to have standing here."114 On the Court's view, the removal of an obstacle to Mr. Orr's success was sufficient to provide him with standing, even if there remained some possibility that he would ultimately be unsuccessful.

In other cases, however, the Court has found that plaintiffs had standing even when there was no realistic possibility under existing law that they would ultimately prevail. For example, in Heckler v. Mathews, ${ }^{115}$ the Court adjudicated an equality claim relating to gendered standards for the award of Social Security survivor benefits. The statute that created the putative inequality also contained a severability clause that stated that if the gendered distinction were invalidated, the equality problem would be resolved by withdrawing benefits to the favored class. ${ }^{116}$ The clause had the effect of dooming plaintiff's chances of ever obtaining the benefits: If he prevailed on the merits, the entire program would be dismantled and he would be left no better off. But despite this fact, the Court held that plaintiff had standing and that the certain result of his "victory" - a mandatory downward ratchet- was not an obstacle to the suit. ${ }^{117}$ The case therefore stands for the proposition that in some circumstances, a court adjudicating an equality claim must ratchet down.

The Heckler result might be explained by concern that Congress would be tempted to manipulate severability determinations so as to shield its actions from constitutional review. ${ }^{118}$ If nonseverability deprived parties of standing, Congress could prevent courts from ever

\footnotetext{
$114 \quad$ Id.

115465 U.S. 728 (1984).

$116 \quad$ Id. at 734.

117 Id. at 738 ("because the right asserted by appellee is the right to receive "benefits ... distributed according to classifications which do not without sufficient justification differentiate among covered [applicants] solely on the basis of sex . . . and not a substantive right to any particular benefits,' appellee's standing does not depend on his ability to obtain increased Social Security benefits.") (citation omitted.)

$118 \quad C f$. id. at 737 (discussing possibility that severability clause might be unconstitutional attempt to deprive Court of jurisdiction).
} 
adjudicating equality claims. But Northeastern Florida Chapter of Associated General

Contractors of America v. City of Jacksonville, ${ }^{119}$ and Regents of the University of California v.

Bakke, ${ }^{120}$ involving challenges to affirmative action requirements, cannot be so explained.

In both cases, a non-minority applicant was denied a benefit and filed suit challenging the constitutionality of an affirmative action plan that favored minority applicants. It turned out, though, that the non-minority applicant could not prove that she would have received the benefit even if the affirmative action plan were not in place. In the absence of that proof, a litigation victory would be virtually certain to produce a downward ratchet, with the non-minority applicant left no better off and the minority applicants made worse off. ${ }^{121}$ These cases are therefore analogous to the situation discussed above where an African American subject to the death penalty sues not to block his own execution, but to require the execution of a comparable white person.

One might suppose that a court would quickly dismiss such a claim, but in the context of affirmative action, the Court has consistently held that the white applicant has standing.

According to the Court

When the government erects a barrier that makes it more difficult for members of one group to obtain a benefit than it is for members of another group, a member of the former group seeking to challenge the barrier need not allege that he would have obtained the benefit but for the barrier in order to establish standing. The "injury in fact" in an equal protection case

119508 U.S. 656, 666 (1993) (holding that contractor had standing to object to affirmative action contracting program even though he could not show that he would have gotten contract under neutral plan).

120438 U.S. 265, 281 n. 14 (1978) (Powell, J., announcing the judgment of the Court) (holding that student had standing to object to affirmative action medical school admission plan even though he could not show that he would have been admitted under neutral plan).

121 This observation brackets the stare decisis effect of the Court's decision, which might lead to an upward ratchet for applicants not before the Court. It also ignores the possibility that, for example, the defendant might respond to a litigation loss by expanding the number of applicants accepted. With regard to the latter possibility, there was no chance that more than one contractor would be awarded the government contract in Northeastern Florida. While it was conceivable that the University of California might have expanded the number of seats at its medical school in response to an adverse ruling, the plaintiff in Bakke made no allegation that this was a likely outcome, and Justice Powell did not premise his holding with respect to standing on this possibility. 
of this variety is the denial of equal treatment resulting from the imposition of the barrier, not the ultimate inability to obtain the benefit. ${ }^{122}$

Although the Court has addressed the problem in the language of standing, the implication of its decisions for the ratchet issue is clear: In at least some cases, the Constitution requires the Court to resolve equality claims in a way that will produce a downward ratchet. ${ }^{123}$ Moreover, these are not cases like Heckler, where there is a risk that the government will deliberately manipulate severability rules so as to shield its actions from constitutional attack. For all that appears, white applicants in these cases would not receive the benefits they seek under nondiscriminatory criteria adopted in good faith. But that fact, and the accompanying certainty that victory for the plaintiff will result in leveling down, in no way impeaches their claim.

It turns out, then, that there is precedent for the Court's insistence on leveling down in Morales-Santana and Barr. What is new, though, is the suggestion that leveling down may become more frequent. To see why this is so, one must unpack the Barr Court's new understanding of the severability problem.

In his plurality opinion, Justice Kavanaugh distanced himself from a severability test that turned on the Court's assessment of what Congress would have intended had it known that a portion of the statute had been invalidated. ${ }^{124}$ Reflecting the values of "the new textualism," he insisted that in cases where the statute contains a severability clause, courts ought to implement

122 Northeastern Florida Chapter of the Associated General Contractors of America v. City of Jacksonville, 508 U.S. 656, 666 (1993).

123 But cf. note $\mathrm{x}$, supra.

124140 S. Ct., at 2349 ("That kind of argument may have carried some force back when courts paid less attention to statutory text as the definitive expression of Congress's will. But courts today zero in on the precise statutory text.") 
it. $^{125}$ Where the statute contains no severability clause, the Court should adopt a strong presumption that it should excise only the offending provision while leaving the rest of the statute in place. ${ }^{126}$ In Justice Kavanaugh's view

The presumption ... reflects the confined role of the Judiciary in our system of separated powers - stated otherwise, the presumption manifests the Judiciary's respect for Congress's legislative role by keeping courts from unnecessarily disturbing a law apart from invalidating the provision that is unconstitutional. ${ }^{127}$

Although Justice Kavanaugh spoke for only three justices, Justices Breyer, Ginsburg, Kagan, and Sotomayor all wrote or joined opinions agreeing that the offending provision should be severed. $^{128}$

If there is in fact a majority supporting Justice Kavanaugh's position, what implications does this position hold for the ratchet question? ${ }^{129}$ There is an obvious problem with implementing the approach in equality cases. Justice Kavanaugh asserts that courts should sever and eliminate only the "offending provision," 130 but in equality cases the offense is produced by the intersection of two provisions, one of which extends a benefit and one of which denies a benefit. Which one should be eliminated?

\footnotetext{
125 Id. ("At least absent extraordinary circumstances, the Court should adhere to the text of severability or nonseverability clauses.")

126 Id. at 2350 ("The Court's cases have developed . . a strong presumption of severability.")

$127 \quad$ Id. at 2351.

128 See id. at 2356 (Sotomayor, J. concurring in the judgment); id. (Breyer, J. joined by Ginsburg and Kagan, $\mathrm{JJ}$, concurring in the judgment with respect to severability and dissenting in part)

129 The severability question overlaps with the ratchet problem, but the two are not identical. See Even $\mathrm{H}$. Caminker, A Norm-Based Model for Underinclusive Statutes, 95 Yale L. J. 1185, 1186 n.3 (1986). Caminker argues that a Court faced with a ratchet question must make three decisions. First, it must decide whether the statutory discrimination is unconstitutional. If it is, then it must decide whether the appropriate remedy is leveling up or down. After making this decision, it is faced with a third question: should the unconstitutional portion of the statute be severed from the rest of it. Id. As Barr demonstrates, though, the second and third parts of the process collapse into each other when the remaining portion of the statute embodies the unconstitutional discrimination. In that situation, severing the offending provision and leaving the rest of the statute intact has the effect of either leveling up or down. See also note, $x$, supra.
}

$130 \quad 140$ S.Ct., at 2353. 
The plurality answers this question by distinguishing between the "exception" and the "rule" with the exception excised and the rule preserved. ${ }^{131}$ As the plurality also wisely concedes "there can be knotty questions about what is the exception and what is the rule." 132 The future implications of its approach are therefore uncertain. ${ }^{133}$

This much is clear, however: The approach requires downward ratchets in an important class of cases. Where the exception extends a benefit to one class and the rule withholds it from another, equality problems must be resolved by making things worse for the advantaged class and no better for the disadvantaged class.

As if to emphasize this point, Justice Gorsuch's partial dissent marshaled all the standard arguments against downward ratchets. He pointed out that from the plaintiff's point of view "it's hard to see how today's use of severability doctrine qualifies as a remedy at all"134 and that "[i]t isn't even clear the plaintiffs would have standing to challenge the government-debt exception."135 What is the point, he asked "of fighting this long battle, through many years and all the way to the Supreme Court, if the prize for winning is no relief at all?"136 Moreover, Gorsuch's point is strengthened by the fact that here the equality claim arises in a free speech context:

[The First Amendment] pushes, always, in one direction: against governmental restrictions on speech. Yet, somehow, in the name of vindicating the First Amendment, our remedial course

\footnotetext{
$131 \quad$ Id. at 2355.

132 Id. at 2354.

133 Consider, for example, Roman Catholic Diocese of Brooklyn v. Cuomo, 592 U.S. ___ (2020). Because of the Covid crisis, New York imposed strict limits on the number of persons who could gather indoors, including at religious services. The Court found that the restrictions violated the Free Exercise clause because similar restrictions were not imposed on "essential" businesses. It seems reasonably clear that "essential businesses" were the exception and the general limitations the rule. Yet the Court did not even discuss the possibility of extending the restrictions to the essential businesses rather than lifting it for the religious institutions.

134 Id. at 2365 (Gorsuch, J., concurring in the judgment and dissenting in part).

135 Id. at 2366 (Gorsuch, J., concurring in the judgment and dissenting in part).

$136 \quad$ Id.
} 
today leads to the unlikely result that not a single person will be allowed to speak more freely and, instead, more speech will be banned. ${ }^{137}$

But none of these arguments persuaded the plurality to abandon a downward ratchet. The plurality thought that the provision of equal treatment fully remedied plaintiff's constitutional violation. ${ }^{138}$ There was no need to worry about deterring future suits because "many individuals and organizations often have incentive to challenge unequal treatment of speech, especially when a competitor is regulated less heavily." ${ }^{139}$ According to the plurality, there was no doubt that plaintiffs have standing to challenge unequal treatment that benefits others, ${ }^{140}$ and the fact that the Court's remedy led to the suppression of more speech was not a source for concern. ${ }^{141}$

We cannot know precisely how consequential this new approach will be until the Court sorts out the vexing distinction between exception and rule. Meanwhile, though, an even more troubling possibility lurks in the background. On some occasions, the Court has thought that the hypothetical possibility of a downward ratchet means that courts should not change the status quo at all. Although this approach is far from dominant, the Court has resorted to it more often than is commonly recognized. The next Part discusses cases adopting this solution to the ratchet problem.

\section{Hypothetical Leveling}

The "neither up nor down" approach has disreputable origins that, one might suppose, would serve to discredit it. Consider, for example, Cumming v. Board of Education. ${ }^{142}$ Cumming was decided in 1899, shortly after of the Court's endorsement of the "separate but

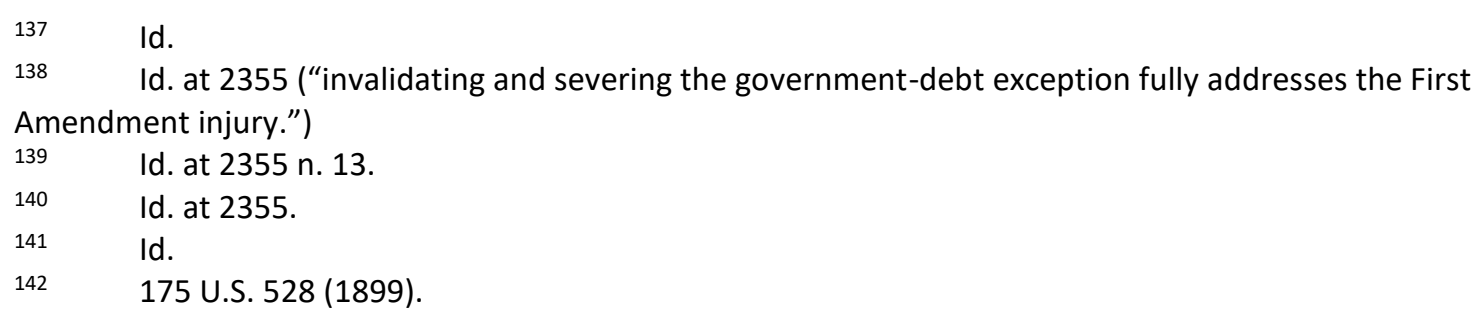


equal" standard in Plessy v. Ferguson ${ }^{143}$ and was written by Justice Harlan, the author of the famous Plessy dissent.

The school board of Richmond County, Georgia had operated both a black and white high school, but voted to close the black high school, supposedly for economic reasons.

Cumming, an African American taxpayer, sought an injunction against paying taxes that supported only a white high school. ${ }^{144}$ The trial court denied that relief but ordered the county not to support the white high school until it funded a comparable black school. ${ }^{145}$ Put differently, it ordered a downward ratchet. The Georgia Supreme Court reversed, ${ }^{146}$ and the United States Supreme Court affirmed that judgment.

Justice Harlan's opinion offers a smorgasbord of arguments, evasions, and qualifications, but for present purposes, here is the key passage:

The plaintiffs in error complain that the board of education used the funds in its hands to assist in maintaining a high school for white children without providing a similar school for colored children. The substantial relief asked is an injunction that would either impair the efficiency of the high school provided for white children or compel the board to close it. But if that were done, the result would only be to take from white children educational privileges enjoyed by them, without giving to colored children additional opportunities for the education furnished in high schools. The colored school children of the county would not be advanced in the matter of their education by a decree compelling the defendant board to cease giving support to a high school for white children. ${ }^{147}$

These are standard arguments against leveling down, and, one might have supposed, the conclusion that followed would be that the Board was required to level up by funding a black high school. But that is not the conclusion the Court reached. Instead, the Court reasoned, because the problem might hypothetically have been solved by leveling down, and because

$\begin{array}{ll}143 & 163 \text { U.S. } 537 \text { (1896). } \\ 144 & 175 \text { U.S., at 528-535. } \\ 145 & \text { Id. at 541. } \\ 146 & \text { Id. } \\ 147 & \text { Id. at 544. }\end{array}$


leveling down benefited no one, therefore there was no requirement to level up or down. ${ }^{148}$ The result is that a putative violation of the equality right is left unremedied.

Another infamous Supreme Court case from the period utilizes a similar technique. In Giles v. Harris, ${ }^{149}$ decided in 1903, the plaintiff alleged that he and other African Americans in Montgomery Alabama had been denied the right to register to vote because of their race, that the denial "was part of a general scheme to disfranchise them" 150 and that "[t]he part taken by the state, that is, by the white population which framed the [state] Constitution, consisted in shaping that instrument so as to give opportunity and effect to the wholesale fraud which has been practised."'151

Writing for the Court, Justice Holmes responded:

The plaintiff alleges that the whole registration scheme of the Alabama Constitution is a fraud upon the Constitution of the United States, and asks us to declare it void. . . . If . . we accept the conclusion which it is the chief purpose of the bill to maintain, how can we make the court a party to the unlawful scheme by accepting it and adding another voter to its fraudulent lists? ... It is not an answer to say that if all the blacks who are qualified according to the letter of the instrument were registered, the fraud would be cured. ... If the sections of the Constitution concerning registration were illegal in their inception, it would be a new doctrine in constitutional law that the original invalidity could be cured by an administration which defeated their intent. ${ }^{152}$

It is not easy to decipher this logic, but the Court's point seems to be something like this: If plaintiff's allegations were proved, that would mean that Montgomery's entire voting scheme was invalid. But if that were true, no one should be permitted to register. Put differently, ruling for the plaintiff would mean a massive downward ratchet, prohibiting whites and blacks alike

148 Id. at 544-45 (putative inequality should not be remedied "by an injunction that would compel the board to withhold all assistance from the high school maintained for white children.")

$149 \quad 189$ U.S. 475 (1903).

$150 \quad$ Id. at 482.

$151 \quad$ Id. at 483.

152 Id. at 486. 
from voting. Because this hypothetical downward ratchet was unthinkable, therefore the state could maintain the unequal and unconstitutional status quo.

Cumming and Giles were decided over a century ago. It is easy to dismiss them as relics rooted in a disreputable past that we have finally disowned. Yet remnants of this approach continue to infect our jurisprudence.

Consider, for example, Justice Thomas's opinion, joined by Justice Alito in Sessions v. Morales-Santana. ${ }^{153}$ Recall that majority found gender discrimination in an immigration statute unconstitutional, but elected to level down by withdrawing the preferential treatment from the benefited class. ${ }^{154}$ Justice Thomas agreed that leveling up was "not . . . an appropriate remedy for any equal protection violation." For him, though, leveling down was not appropriate either. "Because respondent cannot obtain relief in any event, it is unnecessary for us to decide whether [the statute] was constitutional."155 Put differently, he thought that the prospect of a downward ratchet required leaving the putatively discriminatory policy in place.

Justice Thomas did not command a majority in Sessions, but his view finds support in a smattering of Supreme Court precedent. In Levin v. Commerce Energy, ${ }^{156}$ the Court accepted an admittedly milder and less consequential version of the argument. The case dealt with a suit brought in federal court claiming that the state's tax scheme unconstitutionally discriminated against the plaintiff. The Court began its analysis with the familiar observation that in equality cases " $[\mathrm{h}]$ ow equality is accomplished - by extension or invalidation of the unequally distributed benefit or burden, or some other measure - is a matter on which the Constitution is silent."157

\footnotetext{
153137 S. Ct. 1678, 1701 (2020) (Thomas, J., concurring in the judgment in part).

154 See TAN $x x$, supra.

$155137 \mathrm{~S}$. Ct., at 1701 (Thomas J., concurring in the judgment in part).

156560 U.S. 413 (2010).

157 Id. at 427.
} 
But the Court faced a special problem in this case because the Tax Injunction Act $^{158}$ as well as a broader comity doctrine that counseled against federal interference with state taxes prevented federal courts from enjoining the collection of state taxes. That meant that the federal court could not solve the problem by granting the plaintiff a comparable exemption, since such an exemption would entail an injunction against collection of the tax owed by the plaintiff. ${ }^{159}$ This disability might have led to the conclusion that the Court should solve the equality problem by invalidating the exemption - an outcome that would have been permissible under the Tax Injunction Act.

Instead, though, the Court held that the impossibility of extending the benefit meant that it should not entertain jurisdiction over the matter at all. ${ }^{160}$ At least in theory, this resolution preserved the ability of state courts to remedy the inequality with the (small) chance of ultimate review on certiorari by the United States Supreme Court. Viewed in a certain way, it could therefore be rationalized as another case where states were free to ratchet up or down as they chose. But the Supreme Court went beyond following its more usual practice of simply remanding the case to a lower court to resolve the ratchet problem. ${ }^{161}$ Instead, it held that lower federal courts should refused to adjudicate the underlying dispute and therefore left the putative substantive equality violation in place.

On other occasion, the modern Court has adopted more consequential versions of the neitherup-nor-down approach. The Court's treatment of the commercial speech problem provides an example. The Court has held that commercial speech claims can be defeated by outlawing the underlying activity. If the activity itself is illegal, then the government can also outlaw

\begin{tabular}{ll}
\hline 158 & 28 U.S.C. $\S 1341$. \\
159 & Id. at 429. \\
160 & Id. \\
161 & See note $x$, supra.
\end{tabular}


advertising promoting the activity. ${ }^{162}$ This holding leaves the government with the choice of either ratcheting up by permitting the activity and advertising associated with it or ratcheting down by prohibiting the activity and the advertising associated with it. In its now overruled decision in Posadas de Puerto Rico Associates v. Tourism Co. of Puerto Rico, ${ }^{163}$ the Court held that the theoretical possibility of a downward ratchet meant that the government need not ratchet up or down. The Court reasoned that because Puerto Rico could have outlawed gambling altogether, it could also

take the less intrusive step of allowing the conduct, but reducing the demand through restrictions on advertising. . . . It would surely be a Pyrrhic victory for casino owners . . . to gain recognition of a First Amendment right to advertise their casinos . . . only to thereby force the legislature into banning casino gambling . . . altogether. It would just as surely be a strange constitutional doctrine which would concede to the legislature the authority to totally ban a product or activity, but deny to the legislature the authority to forbid the stimulation of demand for the product or activity through advertising on behalf of those who would profit from such increased demand. ${ }^{164}$

Posadas was not an equal protection case, but its reasoning holds obvious implications for equality claims. The argument mirrors the "greater includes the lesser" approach adopted by Justices Harlan and Holmes in Cumming and Giles: Because the government can satisfy constitutional requirements by using the greater power to make things worse for everyone (e.g., both people running gambling facilities and people promoting them), therefore it also has the lesser power of making things worse for only some (people promoting the facilities).

The Court has now overruled Posadas and adopted the "strange constitutional doctrine" that Justice Rehnquist warned against. ${ }^{165}$ Today, at least in the free speech context, the Court insists

162 See Central Hudson Gas \& Electric Corp. v. Public Service Commn., 447 U.S. 557, 563 (1980) (“The government may ban ... commercial speech related to illegal activity.")

163478 U.S. $328(1986)$.

$164 \quad$ Id. at 346.

165 See 44 Liquormart Inc. v. Rhode Island, 517 U.S. 484, 509 (1996) (“We are now persuaded that Posadas erroneously performed the First Amendment analysis.") 
that the theoretical possibility of a downward ratchet "Pyrrhic victory" does not justify maintaining the status quo. Similarly, as discussed above, the Court has held that discriminatory treatment of religious institutions does cannot escape free exercise challenges because of the possibility that the state could eliminate the program altogether. ${ }^{166}$ Nor can most equal protection claims be dismissed because of the possibility of a downward ratchet. ${ }^{167}$

But although the Posadas holding has been discredited, its logic remains powerful and continues to influence how the Court thinks about ratchets. In particular, the approach resonates with a "prediction" theory to resolve the ratchet problem.

One version of the theory is uncontroversial. Consider, for example, the Court's recent statement about how the equality requirement functions in Title VII cases regarding job discrimination: "Take an employer who fires a female employee for tardiness or incompetence or simply supporting the wrong sports team. Assuming the employer would not have tolerated the same trait in a man, Title VII stands silent." 168

The key words are "would not have." Suppose that a woman has been fired for rooting for the wrong sports team, but a man rooting for the same team keeps his job. Then we have a straightforward example of unequal treatment based upon sex. But now suppose that the issue about male-sports-team malfeasance has never arisen. In that event, the court must engage in prediction: what would the employer do if a male case arose. If, hypothetically, the male would also have been fired, then firing the woman does not deny equality. It follows that neither an upward nor downward ratchet is required. 
The prediction theory becomes more controversial in cases where we already know that the equality norm has been violated. Does a prediction that downward ratcheting would be utilized to remedy the violation justify maintaining the status quo? The closely related problem posed by unconstitutional conditions suggests that it might. A putatively unconstitutional condition arises when the government threatens to perform an otherwise lawful act if an individual exercises a constitutional right. ${ }^{169}$ For example, a prosecutor might threaten to charge a more serious offense if a defendant does not plead guilty and exercises her constitutional right to go to trial, ${ }^{170}$ or the government may withhold a tax exemption if the taxpayer does not forego his right to engage in constitutionally protected speech. ${ }^{171}$

There are a variety of solutions to this problem, none of them entirely satisfactory, but a number of commentators have settled on an approach resting on hypothetical downward ratchets. For example, according to Einer Elhauge's synthesis:

a threat to engage in otherwise-lawful action ... is unlawfully coercive only when the threat is contrived, meaning that the threatened action would not have occurred if no threat could have been made. . . . When a threat is contrived, the government benefit would have been provided in the but-for world without that condition, and thus the threat to withhold the benefit penalizes the exercise of a constitutional right. When the threat is uncontrived, the government benefit would not have been provided in that but-for world, and thus withholding the benefit imposes no penalty." 172

\footnotetext{
169 See, e.g., Kathleen M. Sullivan, Unconstitutional Conditions, 102 Harv. L. Rev. 1413,1422 (1988) (defining problem).

170 See, e.g., Bordenkircher v . Hayes, 434 U.S. 357 (1978) (holding that prosecutor does not act unconstitutionally when he carries out a threat made during plea negotiations to reindict the defendant for a more serious offense if the defendant does not plead guilty).

171 See. e.g., Speiser v. Randall, 357 U.S. 513, 518-19 (1958) ("the denial of a tax exemption for engaging in certain speech necessarily will have the effect of coercing the claimant to refrain from the prescribed speech.")

172 Einer Elhauge, Contrived Threats versus Uncontrived Warnings: A General Solution to the Puzzles of Contractual Duress, Unconstitutional Conditions, and Blackmail, 83 U. Chi. L. Rev. 503, 507 (2016). For other proposals that follow similar lines, see Seth F. Kreimer, Allocational Sanctions: The Problem of Negative Rights in a Positive State, 132 U. Pa. L Rev. 1293, 1371-74 (1986); Robert Nozick, Coercion, in Sidney Morgenbesser, Patrick Suppes, \& Martin White, eds. Philosophy Science and Method 440 (1969).
} 
How does this formulation translate into the language of ratchets? In cases where a court predicts that the government would have leveled up by providing the benefit to everyone, then the threat is "contrived" and the condition is unconstitutional. But if a court predicts that the government hypothetically would have leveled down by abolishing a program for everyone rather than extending it to the disfavored class, then the threat is real and is constitutional.

The Court's decisions concerning government funding for abortion illustrate how the approach might work in practice. In Maher v. Roe, ${ }^{173}$ the Court upheld a state regulation that provided poor women with Medicaid funding for live childbirths, but not for nontherapeutic abortions. In Harris v. McRae, ${ }^{174}$ the Court extended Maher to uphold the so-called "Hyde Amendment," which denied Medicaid funding for all abortions except where the life of the pregnant person was threatened or where the person was impregnated by rape or incest.

In each case, the Court answered the argument that the due process clause prohibited this discrimination, by pointing to the hypothetical possibility of leveling down. The state could have leveled down by denying funding to everyone. Because of this theoretical possibility, the Court held, it had no obligation to level up or down. As the Harris Court put the point, "[T]he Hyde amendment leaves an indigent woman with at least the same range of choice in deciding whether to obtain a medically necessary abortion as she would have had if Congress had chosen to subsidize no health care at all."175 Or as the Maher court opined, "An indigent woman who desires an abortion suffers no disadvantage as a consequence of Connecticut's decision to fund childbirth; she continues as before to be dependent on private sources for the services she desires."

\begin{tabular}{ll}
\hline 173 & 432 U.S. $464(1977)$. \\
174 & 448 U.S. $297(1980)$. \\
175 & Id. at 317. \\
176 & 432 U.S., at 474.
\end{tabular}


To be clear, Elhauge himself does not think that his test can overcome equal protection objections. He writes that "sometimes even an uncoerced agreement to a condition or contract would be independently illegal or unconstitutional, usually because it would harm third parties or violate equal protection norms." 177 And although the claims in Harris and Maher both turned on the government's unequal treatment of abortion services, Court's comments were directed solely to the plaintiff's due process arguments.

For now, then, a hypothetical ratchet solution remains decidedly disfavored. It is supported by discredited or overruled cases like Cumming, Giles, and Posadas. It has gained traction with regard to related ratchet problems in the due process context. The Court has resorted to it in the equality context when faced with the special situation posed by Levin, and Justices Thomas and Alito seem to favor it more broadly. But it is not anything like a standard response to equality ratchet questions.

Still, the approach lurks menacingly in the background. Even if no court endorses it, the approach may influence which cases are brought. As Deborah L. Brake has argued, the permissibility of leveling down "confront[s] persons disadvantaged with inequality with a double bind: challenge the inequality and risk worsening the situation for others instead of improving one's own situation, or continue to endure unlawful discrimination." ${ }^{\prime 17}$ To the extent that litigants chose the latter option, governments need not face the choice between leveling up or down, and the hypothetical ratchet solution retains spectral force. ${ }^{179}$

Another reason the approach cannot be entirely ruled out is because of the seemingly powerful logic that supports it. The logic is especially strong when leveling up is impossible.

\footnotetext{
$177 \quad 83$ U. Chi. L. Rev., at 506.

178 Deborah L. Brake, When Equality Leaves Everyone Worse Off: The Problem of Leveling Down in Equality Law, 46 Wm. \& Mary L. Rev. 513, 516 (2004).

179 See TAN xx, supra.
} 
Suppose that a lifeboat is filled to capacity when Jack Dawson swims up to the side. ${ }^{180}$ Dawson is in every way equal to those already on the boat. ${ }^{181}$ Leveling up is impossible because all cannot be saved. Does it really make sense to level down by letting all drown? ${ }^{182}$ Many people will conclude that the inevitability of downward leveling if we insist on equality justifies the inequality entailed in allowing Dawson to drown. ${ }^{183}$ Similarly, one might fairly ask, what is the point of ending high school education for white children if the deprivation will not result in high school education for black children? If a court accurately predicts that finding an equal protection violation would produce only a "Pyrric Victory" for the plaintiff, why should this outcome be treated as a victory at all?

The answers to these questions, if indeed there are answers, depend on why we value equality in the first place. The next Part addresses that problem.

\section{Ratchets and Reasons}

Unsurprisingly, we can find both the roots of the ratchet problem and possible solutions to it by thinking about the reasons for an equality requirement in the first place. Different reasons

\footnotetext{
180 Cf. Titanic (film) (1997).

181 For discussion of a similar hypothetical, see Christoper J. Peters, note x, supra, at 238-39.

182 Cf. United States v. Holmes, 1 Wall. Jr. 1 (E.D Pa. 1842) (upholding murder conviction under similar circumstances, but only because sailors have duty to save passengers).

183 See Christoper J. Peters, note x, supra, at 238-39.

Perhaps Dawson is not "the same" because he is not yet in the boat. But what, then, if the boat is already overloaded and sinking? Does it make sense to let everyone die rather than throwing one passenger overboard? Cf. United States v. Holmes, note $\mathrm{x}$, supra. If the victim is chosen by lot, one might claim that the passengers are treated equally ex ante. Before lots are drawn, each has an equal chance of surviving. But imagine that one passenger on the boat weighs much more than any of the other passengers. Throwing the heavy passenger overboard avoids the necessity of sacrificing two others. On utilitarian grounds, it makes sense to sacrifice the one to save two, but on most accounts, that denies the heavy passenger even ex ante equality. One might claim that, in an extended sense, ex ante equality is still respected because, behind a veil of ignorance, we do not know whether we will be the light or heavy passenger on the boat. But a conception this broad destroys the very concept of equality. Behind the veil, we also do not know our race, age, gender, or gender orientation.
} 
lead to different ratchet rules. If the justices had consistent and coherent ideas about reasons, they could produce consistent and coherent rules.

In this Section, I advance two arguments. First, I hope to show how different, plausible rationales for the equality requirement cohere with different rules for ratchets. Second, I argue that none of these rationales can be mapped onto all of the Court's cases. In fact, the Court has no consistent and coherent ideas about reasons. It is therefore fated to produce inconsistent and incoherent rules about ratchets.

\section{A. Welfarism and Ratchets}

Neoclassical economics provides a useful starting point for thinking about equality and ratchets. As summarized by Louis Koplow and Steven Shavell, "[w]elfare economics ... is equivalent to the moral position that the design of the legal system should depend wholly on concerns for human welfare." 184 Their definition of welfare, in turn, is comprehensive, including "not only individuals' levels of material comfort, but also their degree of aesthetic fulfillment, their feelings for others, and anything else that they might value, however intangible." 185 Kaplow and Shavell contrast their welfarist approach with a "fairness" approach that focuses on "justice, rights, and cognate concepts" and treats "reasons that are not reducible to concerns about individual's well-being as . . . independent evaluative principles - principles employed to assess the desirability of legal rules without regard to the effects of the rules on individuals' wellbeing." 186

Kaplow and Shavell make the striking claim that legal rules should be evaluated solely in terms of their effect on welfare and should not be influenced by whether they meet the criteria

\footnotetext{
$184 \quad$ Louis Kaplow \& Steven Shavell, Fairness versus Welfare 5 (2002).

$185 \quad$ Id. at 4

186 Id. at 5-6 (emphasis in original).
} 
for fairness. Part of their justification for this position is that under certain circumstances, fairness considerations violate the requirements of Pareto efficiency. ${ }^{187}$ Under the Pareto standard, a change that makes at least one person better off but no one worse off uncontroversially enhances human welfare and therefore ought to be made. Conversely, a change that makes at least one person worse off but no one better off is inefficient and should be avoided. ${ }^{188}$ Kaplow and Shavell seek to demonstrate that introducing fairness criteria inevitably leads to this kind of inefficiency. ${ }^{189}$

At least at first, it seems that downward ratchets to achieve equality are straightforward examples of rules that violate the Pareto standard and illustrate the evil that a "fairness" standard produces. ${ }^{190}$ Downward ratchets definitionally make at least one person worse off while making no one better off. It seems to follow that on a welfarist approach, courts should adopt a mandatory upward ratchet. ${ }^{191}$ Where upward ratchets are impossible or unlikely, courts should use the prediction approach and maintain the unequal status quo because remedying the inequality with a downward ratchet reduces human welfare.

Many, but certainly not all, of the Court's cases suggest this welfarist approach. No doubt, the Court's preference for upward ratchets outlined in Part One reflects the intuition that

\footnotetext{
187 See generally Louis Kaplow \& Steven Shavell, Any Non-Welfarist Method of Policy Assessment Violates the Pareto Principle, 109 J. Pol. Econ. 281 (2001).

188 See, e.g., Thomas J. Miceli \& Kathleen Segerson, Defining Efficient Care: The Role of Income Distribution, 24 J. Leg. Stud. 189, 191-96 (1995) (defining Parent efficiency and the Pareto criterion.)

189 Louis Kaplow \& Steven Shavell, note x, supra, at 465-66, 468.

190 Cf. Jean Marie Doherty, Law in an Elevator: When Leveling Down Remedies Let Equality Off in the Basement, 81 S. Cal. L Rev. 1017, 1023 (2008) (characterizing the "Leveling Down Objection" as intensifying "the warning about what a commitment to the intrinsic goodness of equality entails by pointing out that ... it compels us to prefer the kinds of outcomes none of us would actually accept.")

191 Cf. Derek Parfit, Equality or Priority 111 in The Idea of Equality (Matthew Clayton \& Andrew Williams, eds. 2002) ("The mere fact of inequality is not, in itself, bad for people who are worse off. Such inequalities may be naturally unfair. And it would of course be better for these people if they were better off. But it would not be better for them if, without any effects on them, the other people were just as badly off.") But cf. id., at 113-115 (arguing that a state of affairs can be good even though it is good for no one, in a case, for example, where Hitler, unbeknownst to anyone else, suffered for his misdeeds.)
} 
downward ratchets do no one any good. ${ }^{192}$ Similarly, its occasional willingness to tolerate inequality when only a downward ratchet might remedy it reflects welfarist sensibilities. ${ }^{193}$

That said, Part One also discusses many cases where the Court has permitted - and on a few occasions mandated - leveling down. ${ }^{194}$ That result, too, is unsurprising, but only because of difficulties with the welfarist approach, at least as applied to equality.

There are three problems. First, welfarism risks reading the equality requirement out of the Constitution. At its core, equality requires treating people the same to the extent that they are similarly situated, ${ }^{195}$ Of course, that definition produces significant difficulties given the fact that people are both the same and different along an infinite range of dimensions. Perhaps, as some scholars have asserted, that makes the requirement "empty." ${ }^{196}$ It is nonetheless selfevident that sameness can be achieved by either an upward or downward ratchet. It follows that so long as an equality mandate is part of the Constitution, the law must require downward ratchets when upward ratchets are impossible. Put differently, when leveling up is off the table, a rule prohibiting leveling down denies equality and, therefore, violates the Constitution.

Welfarists might be more than ready to concede this point. Indeed, their whole argument is that standards of fairness should be abandoned precisely because they lead to Pareto inefficient downward ratchets. As social critics, they are free to make this argument. Perhaps judges should be free to accept it, but doing so would require them to reject the Fourteenth Amendment's mandate of equal protection. That is asking quite a lot of them.

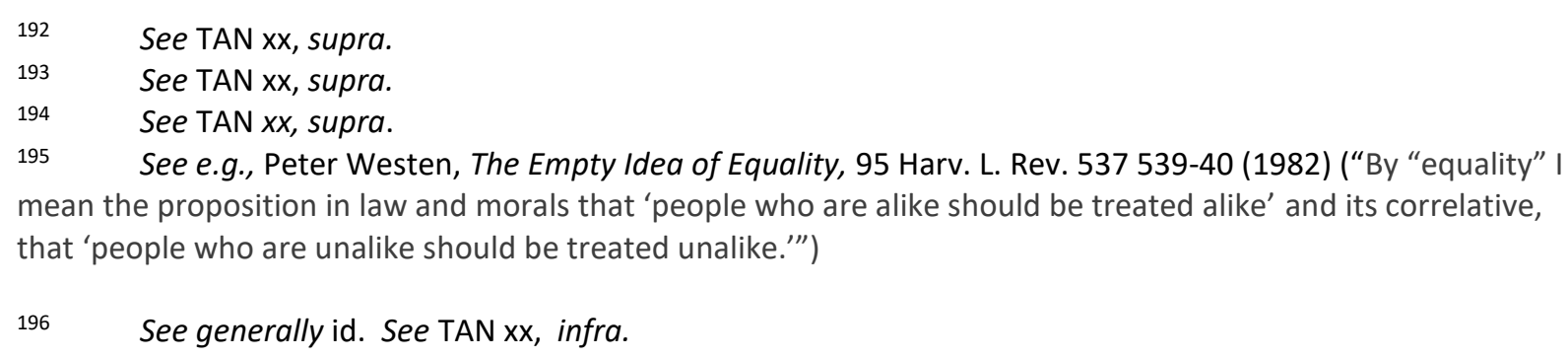


This argument amounts to an external critique of welfarism as applied to ratchets, but there are also two internal critiques. First, Kaplow and Shavell want to make their theory as attractive as possible by defining human welfare very broadly. On their view, it includes "not only individuals' levels of material comfort, but also their degree of aesthetic fulfillment, their feelings for others, and anything else that they might value, however intangible." 197

This broad definition is necessary to make welfarism uncontroversial. Unfortunately, though, it also risks making the standard trivial. As Kaplow and Shavell acknowledge, if people have a "taste" for fairness, then fairness might be welfare enhancing, and the very factor that they wish to exclude gets introduced through the back door. ${ }^{198}$ This point extends to the particular type of fairness embodied in the equality norm. Koplow and Shavell admit that " $[\mathrm{t}] \mathrm{o}$ the extent that people have a taste for some notion of equality (in the sense that they feel better off when the notion is reflected in the law) this taste will be credited in assessing individual's well-being and thus in determining social welfare."199 Although they are not completely clear on the point, ${ }^{200}$ they seem to recognize that downward leveling might be justified when this is true. ${ }^{201}$

Importantly, this approach turns issues about equality into an empirical problem. Downward leveling is justified to the extent - but only to the extent - that people actually do have a "taste"

\footnotetext{
$197 \quad$ Louis Kaplow \& Steven Shavell, note $\mathrm{x}$ supra, at 4.

$198 \quad$ Id. at at 11-12, 467.

$199 \quad$ Id. at 444.
}

200 At times, Kaplow and Shavell suggest that preferences that for fairness are suspect because they are the unthinking product of obedience to social norms. See id. at 467 ("Because social norms have a powerful influence on our minds, it is not surprising that related ideas of fairness seem important. . . Nevertheless, our attachment to social norms, whether due to socialization or evolution, does not imply that analysts should elevate them to the status of independent evaluative principles when assessing legal policy.") Ultimately, though, they conclude that "when a notion of fairness is related to an underlying social norm, individuals may have direct tastes concerning legal rules and the operation of the legal system. . . . Under welfare economics, such a taste is treated as a component of individuals' well- being." Id. 
for equality. Unfortunately, Kaplow and Shavell are mostly silent about how this empirical question might be resolved. ${ }^{202}$ Perhaps an insistence on upward ratchets can be rescued by the intuition that, at least when it is explained to them, people do not actually prefer "fair" outcomes that otherwise leave no one better off. ${ }^{203}$

Suppose that we come to the opposite conclusion and believe that people (most people? all people?) do not experience an improvement in their welfare by the mere knowledge that others are treated as badly as they are. A second internal critique argues that downward ratchets might still be justified under a welfarist approach if they served nonobvious or long-term instrumental goals. Perhaps temporary downward ratchets lead to long term upward ratchets. Perhaps they affect social attitudes toward disadvantaged groups that ultimately produce material improvements in their welfare. Perhaps they influence overall social norms in ways that promote a solidarity and empathic connection that makes people feel happier or more fulfilled. To the extent that any of these things is true, and even if we rule out a mere "taste" for equality, downward ratchets might satisfy welfarist criteria.

The next two sections address these internal critiques.

\section{B. Noninstrumental Equality and Ratchets}

Does a noninstrumental "taste" for equality explain the Court's ratchet rules? On this approach equality is a good in itself that people value regardless of its material consequences. Even if this is true, the resulting rules for ratchets should still include a preference for upward ratchets. Equality is a good, but not the only good. When it can be achieved without cost to either party, that is a preferable outcome. But when upward ratchets are difficult or impossible,

\footnotetext{
202 See id. at 467 (acknowledging that it is an empirical question but not suggesting how it should be resolved).

203 But see generally Richard H. McAdams, Relative Preferences, 102 Yale L. J. 1 (1992) (offering detailed evidence that people have a preference for a position relative to others).
} 
the approach permits downward ratchets. Because, on this view, equality is a good in itself, the benefit from achieving it might outweigh the material costs imposed on the parties. Many although concededly not all - of the Court's cases seem to take something like this approach.

Consider in particular the special standing rules for equal treatment cases. As discussed above, the Court has held that a plaintiff has standing to raise equal protection claims even if she would not receive any material benefit from the remedy. According to the Court, "[t]he "injury in fact' . . . is the denial of equal treatment resulting from the imposition of the barrier, not the ultimate inability to obtain the benefit." 204

At first, this explanation seems inadequate to differentiate equality cases from other standing problems. In most cases, the Court insists that the plaintiff demonstrate both a constitutional violation and that the violation caused the plaintiff to suffer an "injury in fact." Suppose, for example, that the government is illegally polluting a lake with a substance that causes illness, but the plaintiff cannot prove that she actually uses the lake. The Supreme Court has held that she lacks standing because she cannot demonstrate that the illegal conduct is the but/for cause of her injury. ${ }^{205}$ But in equality cases, these two requirements are conflated. The mere fact of constitutional violation provides standing even if the violation produced no material injury.

The rule makes more sense, though, if one thinks of equality as an independent, noninstrumental good. Then the mere denial of equality causes injury even if the remedy is a leveling down that provides the plaintiff with no material advantage. ${ }^{206}$

\footnotetext{
204 Northeastern Florida Chapter of the Associated General Contractors of America v. City of Jacksonville, 508 U.S.656,665 (1983).

205 See, e.g., Summers v. Earth Island Institute, 555, U.S. 488,495 (2009) (plaintiff lacks standing because "hardly likely" that he will use area in question).

206 See Richard H. McAdams, Relative Preferences, note x, supra, at 91-103 (arguing that antidiscrimination law can be justified on the ground that it protects relative positions of groups).
} 
As noted above ${ }^{207}$ arguments along these lines face daunting empirical problems. They proceed on the undemonstrated empirical assumption that people in fact value equality as a noninstrumental good even when equal treatment leaves everyone otherwise worse off. At best, then, the argument clears the way for downward leveling without proving that is justified. Still, it might be possible to isolate cases where it seems most likely that people have a noninstrumental "taste" for fairness. Widely held theories about equality, including expressivism, protection against caste, and protection against subordination might point the way to such cases.

Expressivists endorse legal rules that do no more than send a message about the kind of society we live in and the appropriate role of government. ${ }^{208}$ For example, the Supreme Court has held that voting districts deliberately and ostentatiously drawn along racial lines are suspect because they "reinforce[ ] the perception that members of the same racial group ... think alike, share the same political interests, and will prefer the same candidates at the polls." 209 Similarly, the Justices have sometimes held that religious symbols on government property are unconstitutional when they send a message that members of minority religious groups are "outsiders." 210

\footnotetext{
207 See TAN xx, supra.

208 For general statements of the theory and applications of it to equality problems, see Elizabeth Anderson \& Richard H. Pildes, Expressive Theories of Law: A General Restatement, 148 P. L. Rev. 1503 (2000); Charles R. Lawrence, III, The Id, the Ego, and Equal Protection: Reckoning with Unconscious Racism, 39 Stan. L. Rev. 317 (1987); Deborah Hellman, The Expressive Dimension of Equal Protection, 85 Minn. L. Rev. 1 (2000). For a careful critique, see Matthew D. Adler, Expressive Theories of Law: A Skeptical Overview, 148 U. Pa. L. Rev. 1363 (2000). 209 Shaw v. Reno, 509 U.S. 630, 647 (1993).

210 See Lynch v. Donnelly, 465 U.S. 668, 687 (1984) (O'Connor, J., concurring).
} 
Expressivist theories, taken by themselves, could apply to rights not grounded in equality, but when reinforced by anti-caste and anti-subordination theories it becomes clear why they have special purchase in equality cases. $^{211}$

Some prominent defenders of the equality norm have conceptualized it as a protection against a caste system. ${ }^{212}$ Lower caste individuals frequently suffer material disadvantage, but this disadvantage is not a necessary feature of caste. What is necessary is the existence of certain fixed groups that suffer from stigma and exclusion. ${ }^{213}$ The wider society views members of these groups as disgusting, shiftless, dirty, and untrustworthy. ${ }^{214}$ Those conditions, in turn, are produced by a web of social meaning that the government contributes to by sending a message that members of the disadvantaged class are inferior and, perhaps, not fully human. ${ }^{215}$

Similarly, a condition of subordination is defined by the absence of social power, but that absence cannot be reduced to inferior material conditions. ${ }^{216}$ The Court that decided Brown v. Board of Education presumably had this point in mind when it held that segregated education was "inherently unequal" even if material conditions were equalized. ${ }^{217}$ Once again, the inequality resulted from the social message of inferiority conveyed by separation - a message

\footnotetext{
$211 \quad$ For an elaborate and careful analysis of when expressivism precludes leveling down, see Deborah $\mathrm{L}$. Brake, When Equality Leaves Everyone Worse Off: The Problem of Leveling Down Inequality Law, 46 Wm. \& Mary L. Rev. 513, 571-603 (2004).

212 See, e.g., Cass R. Sunstein, The Anticaste Principle, 92 Mich. L. Rev. 2410 (1994). Cf. Kenneth L. Karst, Paths to Belonging: The Constitution and Cultural Identity, 64 N.C. L. Rev. 303 (1986);

213 Cass R. Sunstein, The Anticaste Principle, at 2430 (associating caste with stigma and lack of self-respect).

214 See Kimberly Williams Crenshaw, Race, Reform, and Retrenchment: Transformation and Legitimation in Antidiscrimination Law, $101 \mathrm{Har}$. L. Rev. 1331, 1373 (1988) (association racism with views of blacks as lazy, unintelligent, immoral, disabling culture, ignorant, criminal, shiftless, and lascivious).

215 Cf. Charles R. Lawrence, III, The Id, the Ego, and Equal Protection: Reckoning with Unconscious Racism, 39 Stan. L. Rev. 317, 339-344 (1987) (associating racism with unconscious beliefs and the social meaning conveyed by government action).

216 For the seminal work on the antisubordination principle, see Owen M. Fiss, Groups and the Equal Protection Clause, 5 Phil. \& Pub. Aff. 107 (1976). See also, e.g., Reva B. Siegel, Equality Talk: Antisubordination and Antidiscrimination Values in Constitutional Struggles over Brown, 117 Harv. L. Rev. 1470 (2004); Ruth Colker, Anti-Subordination above All: Sex, Race, and Equal Protection, 61 N.Y.U. L. Rev. 1003 (1986).

$217 \quad 347$ U.S. 483,495 (1954).
} 
that, in the Court's words, "generate[d] a feeling of inferiority . . . that may affect ... hearts and minds in a way unlikely ever to be undone."218

For these reasons, noninstrumental justifications might be especially important with regard to the equality norm. These justifications also cohere with many of the Court's ratchet rules. For example, they explain the outcome in Prince Edward. ${ }^{219}$ On the facts of that case, downward leveling sent an unmistakable social message about black inferiority. Judicial tolerance of a decision to close public schools entirely to avoid the necessity of blacks coming into contact with whites would have reenforced caste in dramatic fashion. ${ }^{220}$

Unfortunately, though, it is difficult or impossible to reconcile a noninstrumental approach with other strands of the Court's jurisprudence. At the simplest level, any theory that explains Prince Edward cannot explain Palmer because the cases are simply irreconcilable. ${ }^{221}$

But the difficulty goes beyond mere tension between two individual decisions. Consider again the problem of standing. A nonminority person who is not admitted to a medical school has standing to complain about an affirmative action program even if she cannot show that the program caused her rejection. ${ }^{222}$ But what about an African American who witnesses her brothers and sisters murdered in the streets by police officers? The African American witness does not have standing to complain about a constitutional violation even though toleration of

\footnotetext{
$218 \quad$ Id. at 494.

219 See pp xx, supra.

220 See also Tracy Thomas, Leveling Down Gender Equality, 42 Harv. J. Law \& Gender 177, 200 (2019) (arguing that leveling down in gender context reinforces stereotypes and prejudice); Jean Marie Doerty, Law in an Elevator: When Leveling Down Remedies Let Eqwuality Off in the Basement, 81 S.Cal. L. Rev. 1017, 1020 ("where . . the instance of discrimination consists in an injury to status or connotes an exclusionary or discriminatory meaning, leveling down may be insufficient to cure the violation.")

221 See $\mathrm{pp} \mathrm{xx}$, supra.

222 See $\mathrm{pp} \mathrm{xx}$, supra.
} 
racial bias in policing sends a social message that contributes to subordination and caste. ${ }^{223}$ Why not?

Part of the explanation lies in the Court's endorsement of an individualist theory of equality and rejection of a group rights theory. Suppose, for example, an employer provides a pension to male and female employees and requires them to make the same contributions to the fund. From the perspective of group rights, the policy discriminates against men because women on average live longer and will therefore receive more benefits even though they have made the same contributions. But the Court has strongly suggested that the practice does not violate the equality norm because, on the individual level, it treats all employees equally. ${ }^{224}$ Conversely, if women are required to contribute more to take into account of their longer lifespans, the Court has suggested that equality would be violated because individual women would be treated unequally. ${ }^{225}$

Similarly, in the affirmative action context, the rejected applicant has standing because she as an individual has been subject to discriminatory treatment even though the treatment did not result in material disadvantage. The African American witness to police violence suffers injuries associated with the reinforcement of caste and subordination, but on the Court's view these are not individual injuries. Instead, they result from membership in a disadvantaged group. ${ }^{226}$

$223 \quad$ Cf. Allen v. Wright, 468 U.S. 737, 756 (1984) ("abstract, stigmatic injury" does not confer standing). 224 See City of Los Angeles Dept. of Water and Power v Manhart, 435 U.S. 702 (1978) (holding that requirement that individual women pay higher contributions to pension fund than individual men violates equality requirement of Title VII even though women in general live longer than men and, therefore, on average collect higher total pension.)

225 See id. Cf. Bostock v. Clayton County, Georgia,140 S. Ct. 1731, 1744 (2020) ("an employer who intentionally fires an individual homosexual or transgender employee in part because of that individual's sex violates the law even if the employer is willing to subject all male and female homosexual or transgender employees to the same rule.")

226 See Allen v. Wright, 468 U.S. 737, 755 (1984) (stigmatic injury creates standing only to “'those persons who are personally denied equal treatment' by the challenged conduct.") (quoting Heckler v Mattews, 465 U.S. 728,739-40 (1984)). 
One can debate the respective merits of the group and individual rights approaches, but one thing seems clear: The individual rights approach cannot be reconciled with anti-caste and antisubordination theories. Those theories are all about membership in groups. The theories rest on understandings of how social meaning constitutes groups and enforces a hierarchy between them. It makes no sense to say, for example, that the Equal Protection Clause prohibits caste and then to say that it protects only individuals without regard to whether they belong to a lower caste.

For similar reasons, expressivist, anti-caste, and anti-subordination rationales are in tension with the Court's embrace of equal protection formalism. The Court has consistently held that it makes a crucial difference whether a law or government policy facially discriminates on a suspect basis. $^{227}$ If the discrimination is not along suspect lines, it is subject only to "rational basis" review, which is usually easily satisfied. That is true even if the actual effect of the legislation disproportionately harms subordinated groups. Heightened review is appropriate only if there is facial discrimination on a suspect basis or if the purpose behind a facially neutral statute is to discriminate on a suspect basis. ${ }^{228}$

From an expressivist perspective, there are two difficulties with this approach. First, depending on social conditions, discrimination along suspect lines may or may not reenforce caste or subordination. $^{229}$ Imagine, for example, that a local school board with a majority of African American members decides that African American children have distinctive educational needs best addressed by academies designed to deal with their problems. No one is forced to

227 See Personnel Administrator of Massachusetts v. Feeney, 442 U.S. 256 (1977); Village of Arlington Heights v. Metropolitan Housing Dev. Corp., 429 U.S. 252 (1977); Washington v. Davis, 426 U.S. 229 (1976).

228 See id.

229 See Charles R. Lawrence, III, The Id, the Ego, and Equal Protection: Reckoning with Unconscious Racism, 39 Stan. L. Rev. 317, 356 (1987) (arguing that "cultural meaning" of challenged practice, rather than formal discrimination, should determine constitutional question). 
attend the academies, but non-African Americans are excluded. On the Court's approach, the policy would be subject to heightened review and almost certainly invalidated. Is it really plausible that the policy reenforces caste and subordination?

Similarly, because affirmative action policies discriminate on a suspect basis, the Court has subjected them to heightened scrutiny. But whatever might be said for and against these policies, no one can claim that they stigmatize white people or send a social message that white people are disgusting or inferior.

Second, sometimes facially neutral policies do reenforce caste and subordination. Consider, for example, standardized tests used to hire government employees or to determine which applicants are admitted to government-run universities. The tests purport to be neutral, but there are inevitably controversial cultural assumptions and value judgments embedded within them. ${ }^{230}$ Most obviously, many tests assume that there is something called "standard English" and that people who speak and write with different grammatical rules are making mistakes. ${ }^{231}$ Similarly, the tests often assume that test takers share a common store of experiences and assumptions that allow them to make sense of hypothetical fact patterns. Less obviously, the tests are premised on controversial assumptions about which traits are desirable in students and employees. When subjugated students and applicants predictably do worse on these tests, it sends a social message that neutral standards of merit have determined that they are inferior and that their subjugation is justified.

230 See Gary Peller, Race Consciousness, 1990 Duke L Rev., 758, 777 (asserting that liberal integrationism wrongly assumes that "the category of merit is neutral, impersonal, and somehow developed outside the economy of social power, with its significant currency of race, class, and gender that marks American life.")

$231 \quad$ Cf. Washington v. Davis, 426 U.S. 229 (1976) (treating test measuring verbal ability, vocabulary, and reading comprehension in standard English as facially neutral). See Girardeau A. Spann, Race Ipsa Loquitur, 2018 Mich. St. L. Rev. 1025, 1077 (“Given that the population of the District of Columbia in the 1970s was over 70\% black, it is not immediately apparent why a test of white English verbal skills was more appropriate than a test of black English verbal skills.") 
I do not mean to claim that facially suspect classifications never contribute to subordination and caste or that facially neutral classifications with discriminatory effects always do. Instead, these examples illustrate that the messages sent by various government policies are socially contingent. A Court truly devoted to expressivism would need to be sensitive to context and historical location. Equality formalism blinds the justices to just that sensitivity. Because it produces outcomes dictated by rigid rules rather than by careful attention to the message actually conveyed, it cannot be reconciled with an anti-subordination or anti-caste approach.

To summarize: Treating equality as a noninstrumental good explains some of the Court's downward ratchet cases, but the approach is inconsistent with too much of the rest of its jurisprudence to offer a comprehensive solution. Equality standing alone lacks noninstrumental value when it is not tied to social messages that reinforce caste or subordination. The Court has recognized as much by using very loose, rational basis review when classifications are not based on suspect criteria. ${ }^{232}$ But the anti-caste and anti-subordination approaches are inconsistent with the Court's commitment to an equality individualism that rejects the relevance of group membership and to an equality formalism that ignores the actual social messages conveyed by government policy.

\section{Nonobvious Instrumentalism and Ratchets}

A final approach concedes arguendo the welfarist point that equality is only an instrumental good but insists that welfarist critics have understated its instrumental value. Even if downward ratchets have a superficial negative effect on welfare, they sometimes produce nonobvious or long-term gains.

232 See, e.g., Williamson v. Lee Optical Co., 348 U.S. 483 (1955); Railway Express Agency v. New York, 336 U.S. 106 (1949). 
One version of this argument mostly restates the points made in the previous Part. It is easy to recharacterize expressivist approaches as actually grounded in instrumental concerns. On this theory, opposition to government messaging that promotes caste and subordination is not just about the intrinsic evil of the message. Countering these messages also achieves long-term good results that follow for all Americans when caste and subordination are undermined. ${ }^{233}$

Because I have already discussed both the attractions of and the problems with this approach, I will not repeat the arguments here. However, there are other examples of nonobvious or indirect gains produced by downward ratchets that do merit discussion.

1. Competition. Perhaps the clearest case for such gains arises when parties are in direct competition with each other. ${ }^{234}$ Consider, for example, Levin v. Commerce Energy, Inc. ${ }^{235}$ Plaintiffs complained about a state tax scheme that imposed a higher tax on independent natural gas distributors than on competing local distribution companies. As discussed above, the Court ended up dismissing the case because the Tax Injunction Act in effect prohibited an upward ratchet. ${ }^{236}$ In fact, though, leveling down would have improved the plaintiffs' welfare and provided an effective remedy for the putative constitutional violation. By increasing the costs borne by its rival, a downward ratchet would have leveled the playing field, thereby improving the plaintiffs' competitive standing. ${ }^{237}$

233 Cf. Matthew D. Adler, Expressive Theories of Law: A Skeptical Overview, 148 U. Pa. L. Rev. 1363, $1494-95$ (2000) (arguing that meaning of government action can have a moral impact, but not merely because of what the action expresses).

234 See e.g., City of Ladue v. Galleo, 512 U.S. 43, 51 (1994) (noting that underinclusive statutes regulating speech may violate first amendment because they constitute government attempt to give one side or political argument an advantage). See generally Larry Alexander, Constrained by Precedent, 63 S.Cal. L. Rev. 1, 12 (1989) ("equality operates where a good at issue is competitive, so that inequality is tantamount to deprivation.") $235 \quad 560$ U.S. 413 (2010).

236 See TAN xx, supra.

237 It does not follow, though, that under conditions of competition, the equality requirement is always welfare maximizing. Imagine that two people are in need of medicine, which is only effective if 100 units are administered. Suppose that there are only 150 units. The parties are in competition, but the equality norm - 75 
Deciding when a downward ratchet is justified on these grounds requires determining when parties are in competition, and the answer to that question is not always clear. Are robocallers for political candidates in competition with robocalling collectors of government debt $?^{238}$ Certainly not in an obvious way, but it is at least conceivable that some people with limited financial means must choose between paying off government debt and making campaign contributions. Are potential African American victims of the death penalty in competition with potential non-African American victims? ${ }^{239}$ Again, not in an obvious way, but perhaps our society has only a limited taste for violent retribution that might be satisfied without executing so many African Americans if more non-African Americans were executed.

If one is inventive enough, it is possible to fit virtually any case under the competition rubric. Still, there are cases where the Court has permitted or required leveling down and where, as a practical matter, competition does not seem to explain the outcome. It is hard to see how the unmarried men who asked the Court to make their children American citizens in MoralesSantana were in competition with unmarried women who wanted the same thing. It seems much more likely that when the Court ordered a downward ratchet, it advanced neither party's welfare. Similarly, the man who sought to be relieved of his alimony obligations in Orr v. Orr ${ }^{240}$ would get no benefit from forcing women who were not parties to the suit to pay alimony to their spouses. If there are instrumental explanations for leveling down in these cases, they must be grounded in a different theory.

units for each person - does neither any good. See Christopher J. Peters, Equality Revisited, 110 Harv. L. Rev. 1210, 1232-46 (1997) (discussing this and other hypotheticals.)

238 Cf. Burr v. American Assn. of Political consultants, 140 S. Ct. 2335 (2020).

239 See TAN $\mathrm{xx}$, supra.

$240 \quad 440$ U.S. 268 (1979). 
2. Equality as bluff. One such theory relies on the possibility of downward ratchets to encourage the government to grant rights that it might otherwise deny. Consider, as an example, the problem of positive rights - that is, rights to affirmative government measures designed to protect individuals from oppression in the private sphere. These rights are broadly disfavored in American constitutional law, ${ }^{241}$ but advancing equality claims might be an effective tactic to provide indirect protection for them.

For example, in DeShaney v. Winnebago County Department of Social Services ${ }^{242}$ the Supreme Court rejected the claim that the Due Process Clause guaranteed the right of a young boy to government protection from an abusive father. But in a little-noticed, two-sentence footnote the Court pointed to another tactic that might produce such protection. "The State may not, of course, selectively deny its protective services to certain disfavored minorities without violating the Equal Protection Clause. . . But no such argument has been made here." 243

The footnote suggests the possibility of utilizing equality and downward ratchets as a bluff. The state could deny protective services to all children, but, the Court suggests, if it provides the services to some but not others, that failure might violate the equality norm. No one actually wants or expects the government to respond to the violation by depriving all children of protection. Still, a judicial threat that it would have to do so might force the government to extend protection to the disfavored class. ${ }^{244}$

241 See, e.g., Mark V. Tushnet, An Essay on Rights, 62 Tex. L. Rev. 1363,1391 (1984) (arguing that in our culture, negative rights overshadow positive rights). Cf. DeShaney v. Winnebago County Dept. of Social Services, 489 U.S. 189, 195 (1989) (holding that the Due Process clause provides protection from government, not an affirmative mandate for government services).

242489 U.S. 189 (1989).

$243 \quad$ Id. at 196 n.3.

244 See, e.g., Railway Exp. Agency v. People of the State of New York, 336 U.S. 106, 112 ( (1949) (Jackson, J., concurring) (defending equal protection requirement on the ground that "there is no more effective practical guaranty against arbitrary and unreasonable government than to require that the principles of law which officials would impose upon a minority must be imposed generally.") 
One way to think about this approach is that it builds on and modifies the hypothetical ratchet method for dealing with unconstitutional conditions. Recall that the model requires a court to guess whether the government would level up or down if deprived of the choice to provide something unequally. ${ }^{245}$ If a court predicts that the government would level down, then the government need not level up. Perhaps, though, we should not rely on such predictions and instead insist on what economists call "revealed preferences." The government should be put to an actual choice by the credible threat of being forced to level down if it refuses to level up.

Of course, one problem with bluffs is that they are sometimes called. If the government actually responds by leveling down, then we end up with the worst of both worlds: things are made worse for the advantaged class, and the disadvantaged class still lacks the rights that it seeks. The prediction approach allows the inequality to remain when judges predict a downward ratchet. If there is an actual downward ratchet, then we need not rely on guesses. One might therefore think that there is an even stronger case for allowing the government to continue the unequal treatment. But advocates for equality bluffing have a powerful response. The problem is that the threat must be made credible. It will not be credible if courts send a message that they will quickly back down in the face of a downward ratchet.

Does this approach explain the Court's cases? It may be right that courts should not readily back down, but what about cases where there is essentially no chance that the threat will work? Consider again Heckler v. Mathews, ${ }^{246}$ where the Court allowed a party to advance an equality claim despite the fact that the statute's nonseverability clause precluded any possibility

\footnotetext{
245 See TAN xx, supra.

$246 \quad 465$ U.S. 728 (1984).
} 
of an upward ratchet. ${ }^{247}$ What is the point of threatening to level down when the government has effectively precommitted itself to disregard the threat?

Perhaps carrying out the threat might still be justified to discourage such

precommitments. Perhaps the precommitment is less formidable than it seems, and the legislature will repeal the nonseverability provision if put to the test. Perhaps to be really credible, the threatening party must itself precommit to act even when doing so seems irrational. But figuring out whether these strategies actually work is ultimately an empirical matter that cannot finally be resolved by game theory alone. Maybe over the range of cases, sticking to one's guns will produce enough upward ratcheting to counterbalance the losses when the bluff is called. But maybe not. In an odd way, then, advocates of equality bluffing are back in the prediction business that they sought to escape.

A more serious problem with equality bluffs is that, on closer examination, they are not really about equality at all. A true advocate of equality would be satisfied by a downward ratchet, but by hypothesis, the bluffer does not really want to produce one. She is using the threat of downward ratcheting as a mere tactic. The tactic is designed to vindicate some other right not grounded in the equality norm.

For example, at least some people - almost certainly most people -- who invoke equality to attack racial disproportionality in the infliction of capital punishment would not be happy if more non-African Americans were executed. Where this is true, then what passes for an equality argument is really an effort to take advantage of equality's cultural resonance without actually embracing the value itself. Advocates using this strategy are ready to use equality arguments to 
achieve their goals, but their real complaint is not about equality, but about some other principle of justice.

But if that is the real complaint, why shouldn't advocates be forced to defend it? If the death penalty violates the Constitution regardless of whether it is equally administered then it should be invalidated on that ground. If it doesn't, then why should death penalty opponents be permitted to achieve their objectives through equality's back door?

3. Smoking out bad motives. A closely related argument is not merely parasitic on equality's reputation. Sometimes, the requirement of equal treatment serves to "smoke out" bad motives that are inconsistent with the substantive constitutional norm. ${ }^{248}$ Where this is so, the threat of downward ratchets harming the favored group might force the government to give up on its illicit objectives.

The point is most easily illustrated by the content neutrality requirement in free speech cases - the requirement that the Court relied upon in Barr to invalidate the robocall exception for collectors of government debt. If the government prohibits loud sound trucks in residential areas after midnight, it is plausible that it is acting to ensure that residents get a good night's sleep. ${ }^{249}$ But suppose it prohibits sound trucks urging the election of Republican candidates but not those urging the election of Democratic candidates. As noted above,${ }^{250}$ this discrimination is problematic because Democrats and Republicans compete with each other. But even if we put

248 See, e.g., City of Richmond v. J.A. Croson Co., 488 U.S. 469, 493 (1989) ("the purpose of strict scrutiny is to 'smoke out' illegitimate uses of race by assuring that the legislative body is pursuing a goal important enough to warrant use of a highly suspect tool."); Railway Exp. Agency v. People of the State of New York, 336 U.S. 106,112 (1949) (Jackson, J., concurring) (defending equal protection requirement on the ground that "there is no more effective practical guaranty against arbitrary and unreasonable government than to require that the principles of law which officials would impose upon a minority must be imposed generally.")

249 Cf. Kovacs v. Cooper, 336 U.S. 77 (1949) (upholding under First Amendment attack a city ordinance prohibiting any person to use any sound truck or other instrument that emits "loud and raucous noises" on any public street).

250 See TAN xx, supra. 
competition to one side, the discrimination is troublesome for an additional reason. Both types

of trucks inflict the same evil on residents. If the evil is serious enough to ban Republican trucks, why isn't it serious enough to ban Democratic trucks? Content discrimination gives rise to a suspicion that the government is acting out of hostility to the ideas being expressed - a motive that the first amendment makes illegitimate. Put differently, the government's refusal to level down by prohibiting all sound trucks tends to show that it is more concerned with suppressing Republican ideas than with suppressing noise..$^{251}$

Familiar equal protection principles rest on the same reasoning. At its core, the Equal Protection Clause guarantees all inhabitants what Ronald Dworkin once called "equal concern and respect." 252 When some people are treated better than others, the question arises whether the distinction is based upon a legitimate government interest or whether it is based on animus toward the disadvantaged group. ${ }^{253}$ In run-of-the-mill cases, there is a strong presumption that the government is motivated by legitimate, public-regarding reasons, but when classification involves a suspect criterion, it gives rise to the suspicion that the government is acting out of animus. The suspicion can be put to rest only if the classification survives heightened scrutiny. ${ }^{254}$ We might think of the purpose of this scrutiny as assessing whether the government

251 See, e.g., Police Dept. of City of Chicago v. Moseley, 408 U.S. 92, 95 (1972) (associating strict scrutiny for content discrimination with principle that "government may not grant a forum to people whose views it finds acceptable, but deny use to those wishing to express less favored or more controversial views.") See generally Geoffrey R. Stone, Content Neutral Restrictions, 54 U. Chi. L. Rev. 46 (1987); Geoffrey R. Stone, Content Regulation and the First Amendment, 25 Wm. \& Mary L. Rev. 189 (1983). But see Reed v. Town of Gilbert, Arizona, 576 U.S. $155,165-66$ (2015) (law that is content based subject to strict scrutiny even if it is motivated by benign purpose.) $252 \quad$ Ronald Dworkin, Taking Rights Seriously 267 (1977).

253 See, e.g., Romer v. Evans, 517 U.S. 620, 637 (1996) ("laws of the kind now before us raise the inevitable inference that the disadvantage imposed is born of animosity toward the class of persons affected."); Dept. of Agriculture v. Moreno, 413 U.S. 528, 534 (1973) ("if the constitutional conception of equal protection of the laws means anything, it must at the very least mean that the bare ... desire to harm a politically unpopular group cannot be a legitimate state interest.") (emphasis in original).

254 See, e.g., Cass R. Sunstein, Naked Preferences and the Constitution, 84 Colum. L. Rev. 1689, 1698-1702 (1984) (arguing that strict scrutiny in equality cases ensures that there is a public value that supports government action.) 
would have imposed the same disability if the dominant group were also disadvantaged - that is, if there were a hypothetical downward ratchet. ${ }^{255}$ When the scrutiny is "strict," courts are almost never satisfied. Actually leveling down, then, holds the government to its putatively pretextual reason for the measure. In effect, the Court is saying that if the proffered reasons were real, both groups would be disadvantaged. The Court proceeds as if they were real, and orders the disadvantaging of both groups.

There are well-known problems with these equality theories. In particular, defenders of the theories have had difficulty distinguishing either conceptually or empirically between government motives based on mere animus or prejudice and government motives based on legitimate public-regarding concerns. ${ }^{256}$ There is also reason to doubt that judges are better able than legislators to suppress their own unconscious prejudices. ${ }^{257}$ And at least in the first amendment context, the Court has recently insisted on equality of treatment even when content discrimination is not attributable to a discriminatory purpose. ${ }^{258}$

Even if we accept the theories, though, they fail to cohere with the Court's downward ratchet decisions. Consider again the government's decision to make an exception from its robocall ban for government debt collectors. Suppose we assume arguendo that the scheme was

255 See David A. Strauss, Discriminatory Intent and the Taming of Brown, 56 U. Chi. L. Rev. 935, 956-57 (1989) (proposing "reversing the groups" test under which court would ask "Suppose the adverse effects of the challenged government decision fell on whites instead of blacks or on men instead of women. Would the decision have been different? If the answer is yes, then the decision was made with discriminatory intent."). But cf. Personnel Administrator of Massachusetts v. Feeney, 442 U.S. 256, 279 (1979) (discriminatory intent requires showing that decisionmaker took course of action "at least in part 'because of' and not merely 'in spite of' its adverse effect upon an identifiable group.")

256 See, e.g., Laurence H., Tribe, The Puzzling Persistence of Process-Based Constitutional Theories, 89 Yale L. Rev. 1063, 1075 (1980) (asking rhetorically why burglars are not a suspect class given the widespread hostility toward them); Bruce A. Ackerman, Beyond Carolene Products, 98 Har v. L. Rev. 713, 737-40 (1985) (arguing that questions about whether decision is motivated by prejudice inevitably implicate value choices.)

257 See, e.g., Girardeau A. Spann, Race Ipsa Loquitur, 2018 Mich. St. Law. Rev. 1025, 1074 (arguing that the Supreme Court reads the Constitution so as to require white supremacy.)

258 See Reed v Town of Gilbert, Arizona, 576 U.S. 155, 165-66 (2015). 
motivated by government opposition to the ideas expressed by the disfavored class. On this hypothesis, a downward ratchet in effect allows the government to accomplish its unconstitutional objective - the suppression of disfavored speech. Of course, favored speakers are now also disadvantaged, but their loss in no way rectifies the constitutional evil, at least if we assume that the speakers are not in competition with each other. True, innocent bystanders must now bear some of the cost of the government's unconstitutionally motivated restrictions, but that fact does not change the reality that the restrictions remain in place.

A possible response to this argument is that, on the facts of Barr, it is quite unlikely that the government really was motivated by animus against the speakers. The disfavored class consisted of all other robocallers including commercial advertisers, charitable organizations, political organizations, and scammers. Perhaps the government disfavored the speech of some of these groups, but surely not the speech of all of them. The unequal treatment almost certainly stemmed from a desire to favor a certain form of speech - speech necessary to collect government debts and reduce the deficit - not a desire to suppress other speech because of its content. Put differently, the most plausible explanation for the statute is that the stated reason for it - to avoid the nuisance of unwanted robocalls - is not a sham at all and that the exception derives from the reasonable view that the value of some of the calls outweighs the cost. ${ }^{259}$

But if all this is true, then there is no reason for finding the distinction between speakers unconstitutional in the first place. Advocates for the rule against content discrimination claim that we need it to "smoke out" bad motives. If we can be reasonably confident that bad motives

259 See Barr v.American Association of Political Consultants, 140 S. Ct. 2335, 2361-62 (Breyer, J., concurring in part and dissenting in part) (making these points.) See generally Genevieve Lakier, Reed v. Town of Gilbert, Arizona, and the Rise of the Anticlassificatory First Amendment, 22016 Sup. Ct. Rev. 233 (attacking formalism in application of content neutrality requirement). 
are not at work, and if the favored and disfavored speakers are not in competition, then the rule serves no purpose.

To summarize: We are left with two possibilities. If the government is in fact motivated by the desire to suppress certain kinds of speech, then a downward ratchet perversely achieves the government's unconstitutional objective. If the government is not motivated by the desire to suppress certain kinds of speech, then the content discrimination should not make the statute unconstitutional.

A parallel analysis casts doubt on downward ratchets in equal protection cases. As discussed above,${ }^{260}$ in Heckler v. Mathews,${ }^{261}$ the Court held that a statute's nonseverability clause required leveling down to remedy an equal protection violation. Because Congress had directed that the entire statute would fall if part of it were invalidated, a successful lawsuit would result in denial of the benefit for everyone. ${ }^{262}$

Suppose the statutory discrimination in Heckler reflected mere animus toward the disadvantaged class. Then, the "remedy" in effect lets the government achieve its unconstitutional objective. Indeed, the nonseverability clause suggests just how deep the legislative animus was. One explanation for the clause is that legislators harbored so much hatred for the disadvantaged group that, if necessary, they were even willing to disadvantage favored groups so as to avoid the distasteful possibility of advantaging the disfavored group. Ratcheting down in this situation permits the disadvantage to continue in just the cases where the animus is most virulent. ${ }^{263}$

\footnotetext{
260 See TAN xx, supra.

261465 U.S. 728 (1984).

262 See 465 U.S., at 739.

263 See Rebecca Aviel, Rights as a Zero Sum Game, 61 Ariz. L. Rev. 351, 364 (2019) (arguing that threat to level down as a means for enforcing equality “doesn't account for the possibility that hierarchy ... is itself a
} 
Even if we put to one side these disturbing possibilities, there is an additional problem with leveling down so as to "smoke out" unconstitutional motives. Doing so rests on a syllogism that is logically unsound. The premise is that if the government was motivated by the publicregarding reason it has advanced, it would not have made the distinction that it has made. For example, if the government were really motivated by the desire to control noise, it would have banned Democratic as well as Republican sound trucks. The conclusion is that therefore, the government should be held to its pretextual justification, and both Democratic and Republican sound trucks should be banned.

But why does that conclusion follow? If the purported government objective is pretextual, then the legislature was not really motivated by the desire to achieve it. It seems perverse to punish the legislature by insisting on implementing a policy that, by hypothesis, the legislature did not really favor. Of course, the possibility remains that the legislature authentically favored the policy. But then it was not motivated by unconstitutional animus and the classification should not be treated as unconstitutional in the first place.

\section{Ratchets and Equality Ambivalence}

The preceding discussion demonstrates that no equality theory explains all of the Court's ratchet decisions. Welfarist theories conflict with cases mandating downward ratchets and, perhaps, with the equality requirement itself. Noninstrumental theories related to caste and subordination might explain some downward ratchets, but not all of them and, in any event, do not cohere with the Court's overall approach to equality. Competition theories might justify downward ratchets when the parties compete with each other, but the Court has also leveled down in cases where the parties do not compete. "Bluffing" theories may or may not support

cherished good that people might value above more discrete tangible goods associated with tangible government decision-making.") 
leveling down but have nothing to do with the equality norm that the Court purports to be advancing. Downward ratchets to smoke out pretext and bad motives risk giving the government its way in exactly the cases where its motive is the worst and force the implementation of pretextual policies that legislatures do not actually want to advance.

Part of the reason for this wreckage relates to pathologies in constitutional litigation that extend beyond the ratchet issue. There are a variety of well-understood forces that obstruct clean and consistent resolution of constitutional problems.

First, the court is a multimember institution whose members sometimes compromise and logroll to achieve outcomes. ${ }^{264}$ The inevitable result is outcomes that fail to fully satisfy anyone and that cannot be explained by a unitary theory. Changes in membership over time and voting paradoxes are also bound to produce inconsistencies. ${ }^{265}$

Second, at least some of the time, the justices attempt to be "minimalists" who focus solely on the case before them and eschew deep theorizing. ${ }^{266}$ Whatever the virtues of this approach, it leaves them undisciplined by the push toward consistency provided by comparing one case to another or by reconciling an outcome with a broader, justificatory framework. ${ }^{267}$

Finally, our constitutional practice is pluralist in the sense that justices have available to them a variety of modalities that they can use to reach outcomes. Justices are free to choose between arguments based on, for example, text, precedent, policy considerations, or a

\footnotetext{
264 Whether or not the justices logroll between cases currently pending, there can be no doubt that they logroll between pending and future cases. When a justice insists on adjusting the rationale for a decision, she is conditioning her support for the result in the case before the Court on changes in language that will affect future cases.

265 See generally Frank H. Easterbrook, Ways of Criticizing the Court, 95 Harv. L. Rev. 802 (1982) (making these points).

266 See generally Cass R. Sunstein, One Case at a Time: Judicial Minimalism on the Supreme Court (1989) (arguing for this approach).

267 See Tara Smith, Reckless Caution: The Perils of Judicial Minimalism, 5 N.Y.U. J. L. \& Liberty 347, 388 (2010) (attacking judicial minimalism on the grounds that it "lends respectability to rulings that do not uphold the law and the principles the law incorporates.")
} 
supposedly shared moral framework. ${ }^{268}$ This freedom constitutes an open invitation to reach inconsistent outcomes by shifting among modalities in different cases. ${ }^{269}$

But although these general pathologies explain some of the problem, there are also difficulties with the equality norm itself that explain the rest of it. To see the difficulties, consider the most obvious way to clean up the ratchet wreck. Perhaps the Court should simply overrule some or all of the cases where it has tolerated or mandated downward ratchets.

The solution is appealing, but it turns out that embracing it gives up on the only possibility that makes the equality norm truly meaningful. Without it, as Peter Westen insisted in his classic article written almost forty years ago, equality is "empty."270

Westen's argument was subtle, complex, and controversial, but it is easy to map out its basic structure:

1. Equality requires treating people alike to the extent that they are alike and differently to the extent that they are different.

2. But all people are both alike and different across an infinite range of dimensions.

3. To give equality content, we must therefore identify a substantive rule rooted in a conception of justice or law that identifies whether similarities are relevant.

4. But once we have agreed on the substantive rule, then equality has no work to do. We get to the right result by simply following the rule. ${ }^{271}$

\footnotetext{
268 See generally Philip Bobbitt, Constitutional Fate (1982) (describing modalities of constitutional interpretation).

269 Cf. Mark V. Tushnet, Following the Rules Laid Down: A Critique of Interpretivism and Neutral Principles, 96 Harv. L. Rev. 781, 818 (1983) (“In a legal system with a relatively extensive body of precedent and with well developed techniques of legal reasoning, it will always be possible to show that today's decision is consistent with relevant past decisions. Conversely, however, it will always be possible to show how today's decision is inconsistent with precedent.")

270 See Peter Westen, The Empty Idea of Equality, 95 Harv. L. Rev. 537 (1982).

271 Id. at 543-48.
} 
A modern example illustrates the point:

1. Gay and straight marriages should be treated the same to the extent that they are the same but differently to the extent that they are different.

2. But gay marriages and straight marriages are both the same (because, for example, they usually entail a deep commitment between two individuals) and different (because, for example, the individuals have different combinations of anatomical equipment.)

3. To decide whether gay and straight marriages are relevantly similar, we need a rule rooted in substantive justice or law that sets out which characteristics are relevant to the right to marry.

4. But once we have identified the substantive rule about who can marry, we should follow it, and the equality norm adds nothing to the analysis.

The argument is powerful, but it turns out it doesn't quite do the work that Westen expected of it. The theory does not deal with the possibility that for some reason we do not follow the substantive rule in all cases. In that situation, equality is not "empty" if it requires downward ratchets that expand the group for whom the rule is not followed.

Westen himself understood the point. Suppose, he wrote, that justice required all persons in a certain class to receive a particular benefit. Westen recognized that some people accepted the "odd" idea that equality might entail the uniform denial of the benefit if it could not be granted to all. ${ }^{272}$ For Westen, "[t]his interpretation of like treatment, whatever else it may be, is certainly not empty." But, Westen continued "[t]he real trouble with the concept is not that it is

$272 \quad$ Id. at 546. 
empty, but that it is patently absurd. Indeed, it is so preposterous a moral proposition that, if it were what equality really meant, no one would give it a moment's thought."273

Perhaps Westen was right that the proposition is morally absurd, but he was surely wrong when he says that no one would give the proposition a moment's thought. On the contrary, Ronald Dworkin's moral intuition that people deserve "equal concern and respect" is deeply embedded in our culture, as is the realization that when upward ratchets are unavailable, the real test for our commitment to that equality comes when we are confronted with the prospect of a downward ratchet. If we are unwilling to meet that test, then, just as Westen claimed, our commitment to equality is, indeed, "empty." The fact that most people do not think that it is empty suggests why the argument for downward ratchets remains so powerful.

And yet, it is hard to shake Westen's skeptical observations. He forces us to ask opponents of capital punishment why equality should trump substantive justice if equal treatment leads to the execution of more people. Should free speech advocates really be happier in a world where the government suppresses more speech? Do advocates of gender equality who also care about immigration really favor laws that make it harder for men and women alike to get citizenship status for their children? Does it really make sense to take Jack Dawson on board if doing so does not save his life and takes the lives of the other passengers?

Id. See also note x, supra; Derek Parfit, Equality or Priority, note x, supra, at 98 ("Suppose that those who are better off suffer some misfortune, so that they become as badly off as everyone else. Since these events would remove the inequality, they must be in one way welcome, [on a certain conception of equality] even though they would be worse for some people, and better for no one. This implication seems to many to be quite absurd.") 
But Westen's skeptical questions don't quite end the matter. Isn't there also something to be said for the proposition that the passengers should not spend their last minutes on earth fighting over who gets thrown overboard? Perhaps instead they should demonstrate human solidarity in the face of death by all going down together. We are too committed to Dworkin's moral insight to let go of it completely. We prove just how seriously we take that insight when we celebrate seemingly irrational downward ratchets to vindicate it.

Is it any wonder, then, that the justices are ambivalent about equality's entailments? For so long as that ambivalence persists, our ratchet rules will remain a wreck. 
